\title{
ANAYASANIN ÖZERK KURULUŞLARI
}

Prof. Dr. Kudret AYITER

Ankara Hukuk Fakültesi

1961 Anayasası Türk hukuk hayatına bir çok yenilik getirmiş. tir. Ancak denebilir ki, getirdiği yeniliklerin en dikkati çekenlerinden birisi Devlet bünyesi için özerk (muhtar) kuruluşlar yarat. mıș olmasıdır. Bu c̈zerk kuruluşlar Anayasamız içinde ikidjr. Birisi Anayasamızın 120 nci maddesinde ele alınmıs olan Úniversiteler, ikincisi 121 inci maddesinde tanzim edilmis, bulunan Radyo ve Televizyon idaresidir. (Haber Ajanslarının yalnız tarafsızlığmdan bahsedilmektedir.)

Batı memleketleri Anayasalarında bile bulunmayan bu özerk kuruluşların Anayasamıda yer almaları Anyasamızın ileriliğinin bas sebeplerindendir. Bu kurulușların Anayasamıza girmelerinin hiç şüphesiz yakın tarihimizle geniş ilgisi vardır. Denebilir ki, Türk Anayasasını kaleme alanlar ve onu 'kabul edenler bu kuruluşların özerk olmalan gerekliğine bir çok seneler devam eden tecrüibelerden istifade ederek kat'i bir kanaat getirmişlendir.

\section{I - ÜNIVERSITELER :}

A) Türk Üniversiteleri özerk kurulușlar olaraki 1946 yılnndan beri mevcuttur: 4936 sayll Üniversiteler Kanunu 1 inci maddesinin 1 inci fikrasında Universitelerin özerkliğini ifade ettikten sonra 2 nci flkrada Fakültelerin de bilim ve yönetim özerkliğine sahip olduğunu ifade etmiştir. 4936 sayl Ĕğitim Bakanı ile olan ilișkileri cnun hakikî mânada bir özerklik' getirmiş olup olmadı̆̆ını şüpheli burakmıștır. Nitekim 1950-1960 yıllan arasındaki tatbikat bilhassa ögretim üyelerinin Bakanlı emrine alımması, Profesörlük işlemlerinin yürütülmemesi gibi hadiseler de bu özerkliğin hakikatte bulummadığı kanısını umumileștirmiştir. 28.10.1960 tarihli 115 sayılı Kanun ile bir cok maddeleri deł̧iș. 
tirilen 4936 sayılı kanun hakikî mânasıyla özerklik getirmiş, Millî Eğitim Bakanlığıyla ilgili, özerkliğe aykırı hükümleri kaldırmıştır. 1961 Anayasası içinde ifadesini bulan Üniversite özerkliği denebilir ki, 115 sayıl Kanunun esas prensiplerinin vaz ettiği özerkliktir: Üniversite senatolarının çeşitli ișlerde son merci oluşu, Millî Eğitim Bakanının esasa müessir hiç bir yetkisinin kalmaması Üniversite ve Fakültelerin kendi işlerini bizzat görmeleri... gibi.

1946 dan beri Kanun metinleri içinde ifadesini bulmuş olan Üniversite özerkliği yirmi yıllık bir geçmișe rağmen siyasî iktidarda alıșlmamış bir mefhum olarak görülür. Bunu 14.7.1965 tarihli 657 sayılı Devlet Memurları Kanunu ortaya çıkarmıștır. Yirmi yıllık tatbikatına ve Anayasa maddeleri içinde ifadesini bulmasına rağmen, Devlet Memurları kanununun 1 inci maddesi Universite ögretim iiyeleri ile yardınctlarınm özerklikle taban tabana zıt bir rejim içis e alma niyetinde idi. Haibruki Anayasamızı 120 nci maddesi değişı fikralar içinde Üniversite özerkliğini son derece geniş ifade et. miș ve gerekli teminatları da vaz etmiștir: «Üniversiteler, ancak Dev let eliyle ve kanunla kurulur. Üniversiteler bilimsel ve idarî özelliğe sahip kamu tüzel kişsileridir.

«Üniversiteler, kendileri tarafindan seçilen yetkili öğretim üyelerinden kurulu organları eliyle yönetilir ve denetlenir; özel kanuna Æöre kurulmuş Devlet üniversiteleri hakkındaki hükümler saklıdır.

Üniversite organları, ögretim üyeleri ve yardımcları, Universite dișmdaki makamlarca, her ne suretle olursa olsun, görevlerinden uzaklaştırılamazlar.

Üniversite öğretim üyeleri ve yardınıcları serbestçe araştırma ve yayında bulunabilirler.

Üniversitelerin kuruluş ve işleyișleri, organları ve bunların seçimleri, görev ve yetkileri, öğretim ve araștırma görevlerinin Üniversite organlarınca denetlenmesi, bu esaslara göre kanunla dïzenlenir.

Siyasî partilere üye olma yasağı, Üniversite öğretim üyeleri ve yardımctarı hakkında uygulanmaz. Ancak, bunlar partilerin genel merkezleri dıșnda yönetim görevi alamazlar.»

657 sayll Devlet Memurları Kanununun Anayasanın 120 nci maddesine aykın olduŏgu hakkındaki dâva Universiteler tarafından 1965 yllı sonunda Anayasa Mahkemesine intikal ettirilmiştir. Ana- 
yasa Mahkemesi 8 Haziran 1966 tarihinde Resmî Gazetede yaymlanmış olan 4 Subat 1966 tarihli kararında Universite özerkliğini her bakımmindan ele alarak bu konuda bugüne kadar söylenmiş en delil. li ve gerekçeli vesikayı ortaya koymuştur. Dâva konusu ilk bakışta taşıdığı önemi göstermiyordu: Devlet Memurları Kanunu Üniversi1e mensupların tayinleri ile ilgili bir takım hükümler getiriyor ve bu arada Ưniversiteler Kanununun koyduğu bazı prensipler ihlâl ediyordu. Devlet Memurlan Kanumunu o günlerde savunanlar ve onu Üniversitelerin özerkliğine aykırı olmadığını ileri sürenler, Anayasada Üniversitelere bilimsel ve idarî özerkliğin tanınmış ol. duğunu, memur tayini ve maaşının tesbiti gibi hususların bu iki özerkliğe aykırı olmadı̆̆ını; kaldı ki Anayasanın Universitelere malì özerklik vermediğini, Devlet Memurlan Kanununda ise Anayasaya aykırılığı ileri sürülen hususların açıktan açı̛̣̆a malî hüikümler olduğunu tekrar tekrar söylemişlerdir. Anayasa Mahkemesinde dâva açılmasinı gerektiren problemin önemi bu iddiaların içindedir: Bilimsel ve idarî özerklik acaba malî özerklik olmadan düșünüilebilir mi? Memur tayinlerine dair olan hükümler ve tayin usulleri dolaylı yoldan da olsa bilimsel ve idarî özerkliği ihlâl etmiyor maydu?

Burada tetkik konumuzun ana fikrine varmıș bulunuyoruz: Anayasada mevcut olduğu söylenen bir özerklik onu uzaktan ilgilendiren bütün konuları da için almış değil midir? Eğer özerklik Anayasada ifadesini bulmamış başka bir hüiküm ve mesexa malî mevzuat ile ihlâl ediliyorsa, Anayasanın ana kaidesini korumak için malî hükü̈mlerin değiştirilmesi gerekmez mi? Bilimsel ve jdarî özerkligin Anayasada zikredilmiş olması bunun dışında başka bir özerkliğin bulunmadı̆̆ını ifade eder mi?

Kanaatımızca Anayasa Mahkemesinin yukarda zikredilmiş olan kararı problemi Üniversiteler bakımından halletmiştir. Bugün için bu kararın 1şığı altında Üniversite özerkliği arzu edilen genişliğini alabilir. Anayasanm 121 inci maddesirde yerini almış olan Radyo ve Televizyon idaresinde bu problem ise günümüze münakaşa edillmek. tedir. Santyorum ki Anayasa Mahkemesinin 4 Șubat 1966 tarihli kararı bilhassa bu açıdan özerkliğin ana fikirlerini ortaya koymuştur. Anayasamız özerkliği belli sınırlar içerisinde serbestçe hareket edebilme șeklinde ifade eder (1). «Özerk olan bir kurulușun Kanunla belli sınırlar içersinde kalmak șartiyle, kendi hareketlerine

(1) Anayasa Mahkemesinin 4.2.1966 gün ve Esas $965 / 32$, Karar $966 / 3$ sayll kararı. Resmì Gazete 8 Haz. 1966 Sayı 12317. 
hâkim olacak kaideleri de yine kendisinin düzenlemesi gerekir. AnaYasanın 120 nci maddesi Üniversitelere sadece (idarî) ve (bilimsel) alanlarda özerklik tanımışıtır. Şu halde üniversiteler, ilk önce, ka. nunun çizdiği sinırlar içerisinde (kendi kendisini yönetme) yetkisine sahip kamu tüzel kişileri clarak kurulmalıdırlar. Ancak kanun koyucu, bu smırları da dilediği șekilde ve dilediği derecede tayin edemez. Sinırları tayin ederken Anayasanın söz konusı ilkesini gözïnünde tutmak ve (kendi kendini yönetme) imkânımı Üniversite. lere sağlayacak surette bükümler koymak zorunluluğundadır. Yasama yetkisini kullandığından bahisle Üniversiteyi (kendi kendini yönetme) imkânmdan yoksun bırakacak şekilde sınır koyamaz.

Bilimsel özerkliğe gelince; bu daha geniș bir kavramdır. Ana. yasamız bu ilkesiyle Universiteleri; Anayasanın 2 nci maddesinde yer alan ana niteliklere sahip bir hukuk devletinin üniversitesine yaraşır șekilde öğretim, araștırma ve yayın konularını tertiplemek ve yürütmek ve mensupiarını bu yönden çalışmaya sevketmek ser. bestliğine sahip kılmıs bulunmaktadır.

Bu ilkeler üzerinde kurularak Devlet kuruluşundaki ve bilim alanndaki yerini alan Üniversiteye, Devletin herhangi bir idare kademesinin bu özkrkliklerle bağ̣dașamıyacak müdahaleler yapmasına ve kanunlarla da böyle bir müdahaleye imkân verecek bir düzenlemede bulunulmasina imkân yoktur.

Devlet Personel Kanununa konulan malî hüikümler bakımından Üniversitenin kanun șumulüne almmas s sebebiyle Anayasa Mahke. mesince müttehaz karar çok önemlidir. Universitenin açıı̆̆ dâvanın mesnedi, Perscnel Kanununun 34. cia maddesinde, Muhtar idare olan Üniversite ile Merkezî Idarenin bir cüzii olan Devlet Personel Kâ. ıununun müșterek iradelerinin şart kılınmıș olması idi. Anayasa Mahkemesi 4.2.1966 tarihli kararla Anayasaya aykırılığı yönünden madderin iptaline hükmetmiștir.

«Anayasa kcyucusu Üniversiteleri bir Anayasa Kuruluşu olarak kabul etmiş ve Universitelerle ilgili belli başl kurallan da birer birer sayarak göstermiştir. Bunların başında Üniversịtelerin, bilim. sel ve idarî özerkliğe sahip ve Kanunla kurular birer kamu tüze! kișisi olmaları gelmektedir.»

(2) Karayalçm; Universitelerin İdare ve Murakabesi Hirsch Armağanı Ankara 1964 s. 581-694 de düșünülen murakebe sistemi kanaatımızca bilim özerkliğine ve Anayasaya aykırıdır.

(3) Bak. Not. 1. RG. 8 Haz. 1966 Sayfa 4,6 ve 7'e bakınız. 
Univiversiteler bu bakından Anayasanın 112 nci maddesinde ön görülmüș buluran ve bir bütün olduğu belirtilen (İdare) den ayrı nitelikte oldukları ve bu sebeple (İdare) nin genel kuruluşuna dahil bulunmadıkları gibi, aynı maddenin son fikrasında öngörüllmiiș bulunan, kanunla veya kanunun açıça verdiği yetkiye dayamılarak kurulacağı belirtilen (Kamu tüzel kişilerinden) de tamamen ayrı hüviyettedirler. Zira 112 nci maddede öngörülen kamu tüzel kişi. lerini, ih.tiyaca göre dilediği şekilde kurmağa ve ona dilediği görevi ve yetkiyi vermeğe kanun koyucu mezun bulunduğu halde Anayasanın 120 nci maddesi, Üniversiteler bakımından kanun koyucuya bu serbestliği tanımamıș, bir Üniversite kurulması gerektił̆i zaman, ona varlık verecek olan kanunda ne gibi esaslara ve ilkelere riayet edileceğini Anayasa kuralları halinde belirtmiștir.

Bu sebeple Kanun koyucu Üniversite kurarken Anayasanın 120 ıci maddesinde yer almıș bulunan söz konusu kurallara sıkı sıkıya bağlı kalmak zorunluğunda olup ancak bu kurallar dıșindaki alanlarda dizzenleme yapabilmek serbestligine sahip bulunmaktadir. Kanun koyucu bu serbestliğinden yararlanarak söz konusu Anayasa kurallarını doğrudan doğruya veya dolayısiyle zedeleyici nitelikte hükümler koyamaz.

Özerklik, belli sınırlar içersinde serbestçe hareket edebilmeyi gerektirir. Özerk olan bir kuruluşum, kanunla belli sınırlar içerisinde kalmak șartiyle, kendi hareketlerine hâkim olacak kaideleri de yine kendisinin düzenlernesi gerekir.

Bunun scrucu olarak Üniversiteler kendi ögretim üyeleriyle yardımcılarının görevlerini, bu görevlerin gerektirdiği nitelikileri tesbit edebilmeli ve gerekirse bunların Üniversite bakımından taș1$d_{1}$ ğ değere göre sınıflar:dırma ve sınıf içinceki derecelendirme ve kademelendirme işlerini kendisi yapabilmeli, bu konuda başka bir idare kademesi kendisine müdahale ve tesir edememelidir.

Bu hususlardan kanun konusu olanlar, doğrudan doğruya Universite tarafından hazirlanarak bașkaca bir idare kademesinin tasvip ve tasdikine muhtaç olmadan Hükûmet vasitasiyle yasama organna sunulabilmelidir.

Iptali istenen hükme göre «Üniversite, başlıca görevi ve kuruluṣ maksadı olan öğretim, araştırma ve yayın işlerini yürütecek, ve diğer bir deyimle, Úniversiteyi yönetecek personelinin niteliğini tâ yin, onlara verilecek görevlerin Üniversite içindeki sınıf, derece ve 
kademelerini tesbit işlerini kendisi yapamamakta, bu konularda sadece Devlet Personel Dairesine düşüncesini bildirmek yetkisine sahip kılmmakta, bütün bu ișlerdeki son söz Devlet Personel Dai, lesinin takdir süzgecinden geçmekte ve onun münasip göreceği öIçüler içerisinde teklif olarak Bakanlar Kuruluna gidebilmektedir.

Bu suretle Üniversitenin yönetimindeki etkisi aşikâr olan bu konularda Üniversite kenara itilerek (kendi kendini yönetme) yet. kisi büyük ölçüde daraltılmakta ve böylece Anayasanın tanıdığı idarî özerklił̧i zedelenmektedir.

Zira yukarıda da açılandı ı̆ı üzere, idarî özerkliğe sahip bir ka mu tüzel kişisi olan Üniversitenin bu alanda yasama organına hükúmet elile götürebileceği teklif hakkı elinden alınmakta, bu konuda Universitenin karşısma son merci oarak nihai ve geniș yetki ile Bakanlar Kurulu çkarılmakta ve Bakanlar Kuruluna teklif götür. ıne hakkı da Genel İdare Kurulușu içinde, Bașbakanlığa bağlı bir daire olan ve en küçük ölçüde bile özerkliği bulunmayan Personel Dairesine verilmektedir.

Böyle bir netice doğuran hükmün Anayasanm 120 nci maddesiyle Üriversiteye tanınmıs oqlan idarî özerkliği zedelediği meydandadır.

Dewlet Memurları Kanunun (kadrolarla) ilgili hükümlerinin Universiteler hakkında da uygulanmas1 suretiyle Üniversite kadrolarının, Maliye Bakanlığı, Devlet Personel Dairesi ve Üniversite Temsilcilerinden kurulu bir heyetin birleşik kararı üzerine tesbit olunarak Genel Kadro Kanunu içerisinde yasama onganına sunulması esası Üniversiteleri, ihtiyaç duyacağı kadrolarını kendịsi tesbit ederek Bakanlar Kurulu eliyle doğruca Yasama Organına götuirüp orada savunmak hakkindan mahrup etnekte olması bakımınclan idarî̀ ve dolayısiyle bilimsel özerkliğ̣i zedeleyici nitelikte olmakla beraber Anayasanın $120 \mathrm{nci}$ maddesindeki bir diger kurala da aykırılık teșkil etmektedir.

Diğer taraftan Üniversite üyeleri ve yardımcları ile ilgili konularda Devlet Personel Dairesine ve Bakanlar Kuruluna tanımmş olan bu yetkilerin, Üniversitenin öğretim, araștırma ve yayın işlerine etki yapacağı da gözden kaçmamalıdır. Zira bütün bu Univer. site çalışmaları, ögretim üyeleri ve yardımcıları ile yürütüleceğine göre bunların niteliklerinin tâyini, sınıf, derece ve kademelerinin tesbiti yetkisi birincisi kademede, bir Genel Idare Kuruluşu olan 
Personel Dairesinde ve nihâ̂ kademode ve idarenin başı olan Bakanlar Kurulunda bulunduğı takdirde idarenin Universitenin bilim. sel çalışmalarını etkisi altma alabileceğini düşünmekte yanlışlık yoktur. (4)

Yukanda da açıllandığı üzere Üniversiteler, Anayasanın 112 nci maddesinin birinci ve ikinci fikralarında öngörülen Genel Idare Kuruluşuna dahil birer idare cüzii oldukları gibi, aynı maddenin son fikrasına dayanılarak kurulmuș bulunan birer kamu tüzel kişilił̌gi de değildirler.

Böylece Ànayasanın 120 nci maddesine göre kendine özgii bir kișiliği bulunan özerk bir kurulușa, Anayasanın kendisi ile hiçbir ilgisi bułunmayan 112 nci maddesinin ikinci fıkrasında öngörülen ve kurułus ve görevleriyle bir bütün olduğu belirtilen Genel İdare içinde ve o bütünün bir parçası olarak yer verilmesinin, Anayasaya uygun ołmadığı meydana çıkar.

Öte yandan Arayasanın 120 nci maddesinin beşinci fikrasında "Üniversitelerin kuruluș ve işleyiş̧i, organları ve bunların seçimleri, görev ve yetkileri, öğnetim ve araştrrma görevlerinin Universite organlarınca denetlenmesi, bu esaslara göre Kanunla düzénlenir" de. nilmektedir. Görülïyorki Anayasa, 120 nci maddesinin ilk fikrası jle Universitelerin kanunla kurulacağı esasını koymakla birlikte bu. nınia yetinmerniş, aynı maddenin beșinci fikrası ile de Üniversitenin kurulușunun ve bu kuruluşun da işleyişinin maddenin diğger fık. raiarında yer alan ilkeler gözönüne alınmak suretiyle kanunla diuzenieneceği hükmünü koymak gereğini duymuştur.

Bir kurumun kurulușu deyince her șeyden önce o kurumu yü. rütecek personele ait kadrolar hatıra gelir. Zira kurumun temelin den çatısına kadar bütün örgütüü̈ bu kadrolar teşkil eder. Persouti kadroları mevcut olmayan bir kurum, heniiz kuruluş haline geç. memiș demektir. Su halde bir kurumu çalıșir hale getirecek olan personel kadrolarmın, en küuçü̧üunden en büyüŭüine kadar, bütünü. nư kuruluştan ayn düşünmeğe imkân yoktur.

Bir kurumun işleyişi kavramının ise, söz konusu Personel kadrolarının görevlerinin ne olduğunu, kurumun amacına ulaşmak için bu görevlerin ne suretle ve hangi yollarla yerie getirileceğini birbir. leriyle olan ilişkilerini kapsadığını izaha hacet yoktur.

(4) Anayasa Mah. Kararının kısımları sıra ile değil fíkirlerin yakınlığı itibariyle bir araya getirilmiştir. 
Su halde Anayasanın 120 nci maddesinin söz konusu beşinci !ıkrası hükmüne göre, Üniversitenin Kuruluşu ve bu kuruluşun da işleyiși; yani Universitenin hangi amaç etrafında kurulduğu bu na ilaşmak üzere harekete geçirilecek olan her türlii personele ait kadroları ve genel görev içinden bu kadroların her birisine veya bir kaçına düşecek kısmın ne olduğu, görevlerin ne suretle yerine geti. rileceği, personelin tek başlarıa (meselâ öğretim üyesi, dekan, rektör gibi) veya belli görevler etrafında teşkil edilecek gruplaşmalar içinde yapacakları ișlerin hangi yollarla yerine getirileceği üniversitenin ögretim, araştırma ve yayım görevlerinin dışında veya bun. larla ilgili olan idarî görevlerinin ne olduğu ve nasıl yürütüleceği Unniversiteye özgui bir kanunla düzenlenecek ve bu düzenleme yap1lırken de Universitenin geineì idare kurumunun dıșında idarî ve bi. limsel özerkliğe sahip bir kamu tüzel kişisi olduğu esası muhafaza edilecektir.

Görüiliuyorki 657 sayılı Devlet Memurları Kanununun Kadrolarla ilgili hükümlerinin Ünịversiteler hakkında uygulanması yukarda belirtilen Anayasa hükümlerine de aykırı bir sonuç doğurmaktadır.

B) Türk Üniversitelerinin özerkliği 1968 yılı olayları ile de. rinden zedelenmiș, Üniversite bir kriz geçirmiștir. 11 Haziran 1968 günü evvelâ Ankarada başlyyan ve sonra İstanbul ve İzmir Üniver. sitelerine de yayllan harekette Üniversite Ögrencileri Fakülte biná iarını işgal etmişler, Ögretim üyelerini ve Unniversite memurlarını vazifeden ve çalışmaktan alıkoymuşlar ve bazı isteklerinin kabulüne kadar binaları boşaltmamışlardır. "Boykot" ismi verilen ve pasit bir direnme olan boykot ile en ufak bir ilgisi olmiyan bu "ișgal" ha. reketleri Universite Özerkliğini tamamen ihlâl etmiștir. (5) Olaylann tahlili her halde ileri yıllarda daha iyi yapilabilecektir. Bu gün için hadiseleri olduğu gibi kısa kısa izah etmekle yetinmek lâzım.

Öğrenci hareketinde siyasî baskıların rolï bu gün için açık değildir. Araștırmalar bunu da ortaya koymalıdır. Ögrencilerde bir bunalımın bulunduğu doğrudur. Bu bunalım onların sosyal durumlarının kötülüğuinden, yurtları, bursların kifayetsizliğinden geldiği kadar, Fakültelerde muvaffak olmamalarından da ileri gelmiştir. Muvaffakiyetsizlikleri bilgi yetersizliğine ve liselerden çok kötü yetişmiş olarak gelmelerine bağlanıyor, Liselerimiz halen Batının or.

(5) Ayiter, Son günlerin ögrenci hareketleri Dünya $22 \mathrm{Haz} .1968 \mathrm{~s}$. 1 ve 3 Haziran 1968 olaylarımn Anayasa Mahkemesinin Not 1 de zikredilen kararı bakımından da incelenmesi değer. 
ta okul seviyesini tutmaktadır. Öğrencilerin ise kusuru, bu bilgi eksikliklerini tamamlamak çabasını hemen hemen hiç göstermemeleridir. Ögrencilerin bu problemleri senelerden beri mevcuttu, hal edilmeleri için az çaba da gösterilmemiştir. Yurtlar ve Krediler Kurumunun son 7 ylllk faaliyetine bakmak yeter. Daha fazlası da her zaman yapılabilir. Öğrenci hareketlerinin sebepleri sirf bunlar $\mathrm{m}$. idi? Bunu ilerde ögreneceğiz. Üniversite bakımmndan önemli cihet bir dönüm noktasının yașanmış olması, zor ve cebrin müesseseye girmesi olmuştur. Bir baskı grubu tarafindan Universite özerkliği ihlâl edilmis ve suç işlenmiștir. Ögretim üyeleri günün şartlarına göre bazı isteklerin kabulü ile bazı hadiselerin önleneceł̣i gerekçe siyle hareket etmeyip, verdikleri kararla müessesenin nasıl bir değişikliğe uğrıyacağını hesaba katmak zorunda idi. Ủniversite muh. tariyeti için yllardan beri müicadele edilmiș ve 1933-1946 ve nihaye 1960 ve 1961 yıllarındaki adımlarla Garb memleketlerinde emsali az bulunan muhtar bir Üniversite kurulabilmiștir. Üniversite bu muhtariyeti korumakla yükümlüidür. Ögrencilerin baskı ve tazyik: leri altında, hele sonundá memlekette isyan çıkabilir, gibi görüşler altında Üniversite muhtariyetini yok etmeğge kimsenin hakk1 yok. tu. Bu gün alınan kararlar alttan gelen bir tazyikle alınmış kararlar$\mathrm{d}_{1}$ r ve muhtariyetin yok olmasını tevlit etmiștir. Üniversite nasıl 1960 yllında üstten gelen tazyike dayanmışsa, ve bu dayanmanın sonunda bu günkü Anayasa teminatını. elde etmişse, alttan gelen tazyike dayanacak kadar şahsiyet sahibi olmalıydı.

1968 hareketlerinde Kanun dışı ortam meșru ilân edilmiș, bundan böyle Türk Hukuk hayatında büyük bir gedik açılmıștır. Üniversite Kanunî nizam için direnememiş ve Devlet seyirci kalmuştır. Üniversiteler dayanışma ve direnme de gösterememiştir. Direnme bir inat, ögrencileri «dinlememek» değil, Kanunî sistemin ve özerkligin savunması olacaktı. Ögrenciler bunu anlryamadı̆̆ı gibi, Úniversite de direnmeyle özerkliğini koruyacağını anlıyamadı. 1960 da sivasî baskılara dayanarak bir kuvvet olduğunu gösteren Üniversite, kendi içinden gelen baskıya hâkim olamamış, özerkliğini teslim et. miștir. Oysa, özerklik bakımınđan 1960 yllndaki direnme bunun yanında önemsizdi. 1960 da bir kuvvet olan Üniversite 1968 da zaafı temsil etmiş, ilerisi için 1960 da nüimune olmușken, 1968 de korku vermiștir. Türk Kültür hayatının büyük bir dayanağl gitmiștir. Bu 40 yllık Türk Universitelerinin en zayıf anı olmuștur. Nasıl insanlara büyuik șahsiyet oldukları göstermek fırsatı nadiren düşerse - bazısına bu fırsat hiç dïșmezse - müesseseler ve onların idarecilerine 
de bu fırsat az düşer. Üniversite 1968 de bu şahsiyetleri ortaya koyamamıștır. Kurulușlar zayıfmıs, Kurullar ve kilit noktalarındaki idareciler Üniversitenin özerkliği ve geleceği ile ilgili problemleri göremediler. Universiteler, sonunda, yahnız tazyikle iș görür müesseler diye tanındı. Hakikaten öyle mi idi? Unniversiteyi ıslah ve tan. zim etmek istiyen ögrencilerin yalnız lise mezunu olduğu unutulma. malıdır. Tarihte nerede ver ne vakit lise mezunları Universiteleri islah etmişlerdir, Universitenin problemlerini anlamışlardır? Anka. ra Dil Tarih ve Cơgrafya Fakütesinden, Filoloji gruplarnndan lâtincenin kalkmasın 1 istemek ve bu isteklerinde muvaffak olmak bu ögrenci hareketinin en tipik ve unutulmaz vak'ası olarak kalacak. tır. Islahat istiyen ögrencilerin imtihanları kolaylaştıran taleplerden fazlasın getirmemiș olması bazıların hayrete düșürdü. Halbuki, lise mezunu öğrencilerin bundan daha ötesini görmeleri mümkün değildi. Görüss sahaları bu kadardı. Asıl köklı̈ reformları his et. mediler bile, köklü reforın diye ortaya çıan bir kaç söz de o ma. hiyette değildi. Geride ne kaldı? Imtihan yönetmeliklerindeki deği. siklik için Üniversitenin muhtariyetini ynkmıya değer mi idi? Öğ renciler şimdi elleri ile yıktıkları nüesseselerin harabeleri karsılsinda bu yangundan ufak bir mal kaçırmış insanlar olarak kaldı. Yarın bu müesseseler artık kendi işlerine yaramıacak. Hiç bir şey hareketin yanlış bir ortamda inkişaf ettirildiğini işgal edilen bi. nalara kurulan barikatlar kadar iyi göstermemiștir. Bu barikatlar kime karşı idi, Ögretim üyelerine karşı olmadığı muhakkaktı, di. ğer ögrencilere karşı ise hareketin iddia edilen mahiyeti yoktu, yanlıṣlık șurada idi: bu barikatlar olmaması gereken, yanlış ve inandır. mıyan yerlerde idi, ve kanunların çiğnendiğinin timsali olmușlar. dır. Bu barikatlar bir öğrenci zaferinin değil, Üniversite yıkılışının alâmeti kalmıștır. Öğrenciler Problemleri ve hal tarzlarını ayırabi. lecek dirayeti gösterememişler kendi mïesseselerini yıkmışlardır. Ögrenciler bir az ışık için veya bir az ısınmak için kendi evlerini tutuşturan insanlara benzemişlerdir. Halbuki bu «binalar», bu "kuruluşlar» onlara daha çok lâzım olacaktı. Ö̌rencilerin de Üniversitenin bir unsuru olduğu, onlarm da özerklikten nasipleri» bulunduğu söylenerek hareketin özerkliğin hudutları içinde kaldığı şek. lindeki izah tarzı durumu aslâ deł̧iștirmez. Özerk bir kuruluş kendi iç bünyesindeki bir patlamaya hâkim olamayıp, kendi bedenin. de yaralanırsa, durum değișmez: «Özerklik zedelenmiș olur». Biz

(6) Bundan sonra TRT şeklinde kisaltılacaktır. 
bir iç hastalıktan veya dıştan gelen bir yaralanmadan ölen arasında ayırım yapmayı: bizim için netice önemlidir.

Bașka memleketlerde (meselâ Almanya, İtalya, Fransa da) on yılda güçlükle tamamlanabilen reform tasarılan karşısında bizde üniversitelerin bir kaç ay içinde maddî ve manevî tazyik altında ve neticeleri derinligine düșünülmeden aldakları reform kararları çok zavallı kalmạktadır. Bu kararların bu şekilde ve samimiyetle jnanmadan alınışları Fakültelerde bir yıkıntı manzarası vermiş, dayanaklı olan manevî unsurlarını kaybedişleri olmuştur.

Haziran 1968 ayında Ankara, İstanbul, Izmir ve Eskişehir'de cereyan etmiş olan ögrenci hareketlerinin ardından bir soru kaldı; halk efkârı bu soruya cevap aramakta ve durumu bu sonunun cevabına göre hal etmek istemektedir: Bahsi geçen öğrenci hareketleri hukurken ne idi? Öğrenciler bareket tarzları itibariyle hakl mi idiler yoksa yaptıklan bir suç $\mathrm{mu}$ idi?

Halk efkârını billhassa iki husus şaşırtmaktadır: Bir taraftan Büyük Millet Meclisinde bu hareketlerin birer suç tȩ̧kil ettiğini ileri sürenler olmuș, diğer taraftan "haklı bir direniş". "meşru bir müdafaa» olduğu söylenmiştir. Diğer taraftan ögrenci isteklerinin bir kısmı Fakültelerin yetkili kurulları ve Senatolar tarafından kabul edilmiş, «burada bir suç vardır, bu talepleri biz tetkik etmeyiz» denmemis, diğer taraftan Savcılar son giinlerde harekete gleçérek "işgal" hareketlerine ön ayak olan, onlara fiilen iştirak edenler hakkında tâkibata geçmiștir. Halk efkârı, hakhı olarak, bu çelişik durum karşısında şüiphe içindedir ve hakkın kimin tarafın. da oldugundan șüphe etmektedir.

Her şeyden evvel burada bir kaç hususu bir birinden dikkat. le ayırmak gerekir. Öğrenci isteklerinin arasında haklı olanlar vard. Ancak bunların varlığı, ögrenci hareketinin kanunlara aykın1 ve suç olan tarafını hakl göstermez. Bir misalle durumun açı. lanması yerinde olur: Bir kimsenin malı başkasının eline geçmiş clabilir. Kendi miilkï dahi olsa bunu bizzat zorla diğerinden ala. maz, bu yola giderse yerine göre suç işlemiş olabilir. Malını mahkeme yolu ile geri alacaktır. Başka bir deyimle aslında haklı olan bir talep seçilen yollar bakmmından o kimseyi haksız bir duruma sokabilir.

Öğrenciler bir boykot hareketine girebilirler, dersleri ve imti. hanları tâkip etmezler ve bu suretle isteklerini iust makamlara 
kưvetle duyurabilirlerdi. Bu hareketin kanuna aykurı hiç bir yönü bulunmaz, fakat ögrenciler bakımından - hakka uygun davranıșları yönürnde de - daha etkili olábilirdi. "Ișgal" hareketlerinin birer suç tegkil ettiłine en ufak bir șïphe yoktur, bu gün bunun suç ol. madığı bususunda Politika adamlarınm, hattâ-esefle söylemek lâzım-bazı ilim adamlarmın yapmıya çahıştıkları zoraki izahlar ve teviller kimseyi ikna edemez. «İsgal» hareketleri Türk Ceza Kanununun o kadar çeșitli maddelerini ihlâl etmektedir ki birini veya ikisini yan izahlarla hadise dışında brrakmak istiyen, hepsine şâ. mil bir kaçamak yolu bulamaz. Türk Ceza Kanunu 254, 255, 256, $260,266,311,313,516$ ve bazi Fakültelerdeki hadiselerin c̈zelliklerine gëre daha başka maddeleri ihlâl edilmiş ve suç işlenmișțir, me. murların vazifelerini yapmaktan men edildikleri, kamu hizmetinin aksetildił̆i, bu gaye ile kamu binalannın işgal edildiği ortada. dar ve hiç bir yol bu suçluluğu ortadan kaldıramaz.

1968 yıl Haziran olayları bu bakımlardan Uriversite özerkliğinin bir krizi olmuștur. Öğrenciler, suç yolu ile, tazyikle netice elde etmişlerdir. Bu neticeyi elde etmemeleri, Fakültelerin $\mathrm{su}_{\Im} \mathrm{du}$. rumu ortadan kalkmadıkça ögrenci talepleri hakkında karar vermemeleri gerekirdi. Burada sosyal bünyemizde nasil ve ne vakit kapanacağı telli olmayan bir yara da açılmıştır. Ö̆renci hareketinin ağırlık noktasının, kendi imtihan yönetmeliklerinin, kendi yakın menfaatlerinin oluşu da çok üzücüidür. Bu isteklerini elde edince bütün hareket dağllmıș, sükùn andet etmiştir. Öğrencilerin biiyüik jdealler peşinde koşmadıklan, meselâ bütüin bunalımlarının sebəbi olan kifayetsiz Lise ögretiminin doŏgu yola konması için kendilerini ileri atıp, sonuna kadar dayanmaları çok acıdır. Halbuki bu problem Türkiyenin ana problemidir ve bunun için geniş hareket. lere girişmek, bunu duyurmak gerekmektedir. Ögrencilerin bu an liselerde okuyan ve yarın okuyacak olan kardeșleri ve belki çocuk. Jarı için seslerini duyurmalar, bu güne kadar bu sahada hocalannın sarf ettikleri gayrete katılmaları lâzımdı. Uzun vâdelì bir öğ renci hoca birliği inanarak, baskılardan uzak degabilirdi. Halbuki ögrenci, kendi talebini zor altında kabul eden hocasına da bir daha güvenemez.

Ortada kalan sorular şunlardır? Ögrrencilerin tazyiki ile alınan kararların hukukî değeri nedir? Anayasaya aykırı hareketin karşı. sında Üniversite özerkliğinin yeteri derecede korunmadığı, bunuı nä̈eyyideleri kulunmadı̆̆ görülmüiștür. Kabul ediliş tarzı ve mahiyetleri itibariyle, ögrenci isteklerinin Anayasaya aykırnlığ Ana 
yasa Mahkemesince tesbit edilebilecek midir? Bu günki sistemimiz de bu mümkün deģildir. Anayasa teminatı yetersiz görünmektedir. Gereken iptal dâvalarnn açmak için yollar yoktur. Anayasa Makkemesi alınan kararların şekil şartlarını inceliyememektedir.

\section{II - RADYO VE TELEVIZYON IDARESI.}

A) Anayasamızın ikinci özerk kuruluşu Radyo ve Televizyon Idaresidir. Anayasa Mahkemesinin yukarda sıraladığımaz fikirleri bugüin TRT'nin özerkliği konusunda özel bir önem taşımaktadır. TRT Kurumunun özerkliği üzerinde yeni durulmakta, konu henüz incelenmiye ve anlaşılmıya başlannıș bulunmaktadır.

Anayasanın TRT ile ilgili maddeleri șunlardır :

\section{IV - ÖZERKI KURULUŞLAR.}

b) Radyo ve televizyonun idaresi ve haber ajanslar.

Madde 121 - «Radyo ve televizyon istasyonJarının idaresi, özerk kamu tüzel kișiliği halinde, kanunla düzenlenir.

Her türlï radyo ve televizyon yayımları, tarafsızlık esaslanna göre yapılır.

Radyo ve televizyon idaresi, külttür ve eğitime yardımcılık görevinin gerektirdiği yetkílere sahip kılmır.

Devlet tarafindan kurulan veya Devletten malî yardım alan haber ajanslarınin tarafsnzlığı esastır.

\section{VI - BASIN VE YAYINLA ILGILI HÚKƯMLER.}

e) Basın dıșı haberleșme araçlarından faydalanma hakkı.

Madde 26 - «Kișiler ve siyasî partiler, kamı tüzel kişileri elindeki basın dıșı haberleşme ve yayın araçlarından faydalanma hakkına sahiptir. Bu faydalanmanın șartları ve usulleri, demokratik esaslara ve hakkaniyet ölçülerine uygun olarak Kanunla düzenlenir. Kanun, halkin bu araçlarla haber almasını, düișïnce ve kanaatlaira ulaşmasını ve kama oyunun serbestçe oluşumunu kösrekleyici kayitlar koyamaz».

Anayasanın 121 inci maddesi :

1 - Özerk kamu tüzel kişisi olan Radyo ve Televizyon idaresinden ve, 
2 - Tarafsız haber ajanslarmdan bahs etmektedir.

Tețkikimizin konusunu yalnız özerk TRT idaresi teșkil edecektir.

TRT Özerkliğinin nedenlerini, doğușunun özelliğini bilmeden bu özerkliğin iç büryedeki tesirlerini hesaba katmadan, özerliğe dolaysiyle tesir edden veya onu kısitlayan' âmilleri bilmeye imkân yoktur. Her şeyden evvel Anayasanın ana karekterini ve hukuk üstünlüğü prensibini kısaca ele almak gerekecektir. Bugünkü Anayasamı. Devletin Hukuka uyma miikellefiyetini getirmiş ve bu sahada en yüksek murakabenin Anayasa Mahkemesine ait olduğunu if æde etmiștir. Anayasanın üstünlüğüi prensibi Türkiyeye bu yeni nizamı getirmiştir.

Diğer taraftan Anayasa Mahkemesi, kendi kararları ile hukuk ïstiunlüğuinui ve devletin șeki hakkunda görüișünüide belirtmiştir Anayasa Mahkemesi bu yönden Anayasayı tefsir etmis, tahlil etmiş, doğuşunu - komisyondaki çalışmaları da göz önünde tutarak - umum nizam içirde izah etmiştir. Anayasa Mahkemesi - bilhassa Unniversiteler hakkındaki kararı ile - özerklik hakkında da görüşünü belirt. miștir. Bu kararlarm 1 şı̆ı altında TRT özerkliğinin incelenmesi ge rekecektir. TRT özerkliği ilk defa 1961 tarihli Anayasa ile ortaya çkmıștır, Mefhum Türk İdarecileri ve Hukukçuları için yeni idi. Bir müddet anlașılmamasını, yadırganmasını, anlayışa karşıamak gerekir. bu özerklik Anayasanın 121 inci maddesinde, birinci flkrada bütün maddeye șamil genișlikte ifadesini bulmuștur. Anayasamiz bu maddesi ile batı demokrasileri arasında en ileri mevkidedir. Alman Anayasasında bu c̈zerklik hükmü olmadığ halde Alman Anayasa Mahkemesi bir kararı ile fikir hürriyeti bakımından özerkliği radyo ve televizyon idaresi için kabul etmiștir (7). Ingilterede BBC fiilen bu c̈zerkliği uzun senelerden beri elde etmiştir. Bizde ise Ana. yasa himayesi altında elduğundan diğer batı memleketlerinden daha ileri olduğumuzu haklı olarak söyleyebiliriz.

B) TRT özerkliğini konunun genel hükümleri ile düșünelim.

Hükûmet șekilerini veya başka bir deyimle, siyasî iktidarın kullanılmasını esas tutarak devletleri ayıracak olursak, (hukuk üstünlügüi devleti) ile (otorite üstünlüğ̈̆ devleti) sinıflanmast yapilabilir.

(7) Alman Anayasa Mahkemesinin 28.2.1961 gün ve 2 Bv. 1-2/60 sayll karar1 Entscheidungen des Bundesverfassungsgerichts 12. Band. Tübingen 1962 s. $205-263$. 
Hukuk üstünliü̆u melhumu ile bir yandan siyasî toplumun erismek istediği gayelerí teşkil eden temel ülküler, öte yandan, bu ülküleri gerçekleştirmeğe elverişli müesseseler kastedilir. Hukuk üstünliuğ̣i 1 Łâkkkisinde, hükŝmeti hukuka tabi olmağa zorlayacak bazı usulle rin mevcudiyeti zaruridir. Hukuk üstünlüğüinün geleneksel telâkkisi, ferdin keyfiliğe karșı korunması ve devlet kudretinin tahdididir. (8) Yeni Delhi toplantısmda Milletlerarası Hukukçular Komis. yonu hukuk üstünlügüniün «ferdi, keyfi bir hükûmete karșı korumak ve ferde insanlık haysiyetinden faydalanmak imkânını vermek için zarurî oldukları sabit clan prensipler, müesseseler ve usuller» olduğunu belirtmiștir (9). «Hukuk üstünlüğü prensibi hür bir topIumun temel değerlerine dayanır. Hür toplum ise üyelerinder her birinin hür düssüncesini tam mânasıyla ifade imkâmını bulduğu aherkli bir ortamdır. Hukuk üstünlügü prensibi fertlerarası ve fert ve devletlerarası münasebetlerin kuvvetle değil, hukuk kuralları ile düzenlendiği mânasını taşır,» (10)

«Hukuk üstünlïğ̈i prensibinin neticelerinden en önemlisi hukuk kuralları arasunda husule gelen farklardır. Idarenin Kanuna lẩbi olması esası buradan çımıștr. Filhakika, idarenin karar ve işlemleri Kanuna aykırı olamaz. Kanun ise Anayasaya aykırı hüküm sevkedemez. Bu esaslar (Anayasa Kontrolu) ile sağlanmış olmalı. drr.»

«Memleketimizde siyasî hayatın gelișmesirnde ve tek parti dev. rinden yarı demokrasiye geçişte "Hukuk Üstïnlüüü Devleti» telákkisinin mühim rolü olmuştur. Türkçede sadece (Hukuk Devleti) de denilmekte olan bu devlet idaresi rejimi aslında bir plebisitten başka bir şey olmayan 1950 genel seçimleri neticeleri ile Tüirk hal. kmın uygulanmasını istediği devlet tarzı olmak üzere ortaya çımıș. 1. 1950 de halkın iktidara getirdiği Demokrat Parti hukuk üstünlii. gäi devleti telâkkisine yer vermemiştir. Bugün Türkiye Cumhuriyeli Anayasasında bilhassa 2. maddesirde kullanlan «Hukuk Devleti» terimi ile ifade olunan (Hukuk Ustünlüğüi Devleti) dir.» (11)

Buraya kadar tetkik ettiğimiz Hukuk Üstünlügünü Devletlerinin vasıfları Anayasa üstünlüğ̈̈nde kendini gösterir. Anayasa diğer bü-

(8) B. N. Esen : Anayasa Hukuku. Genel Esasları. Ankara 1963 s. 160 ve devams.

(9) Delhi Beyannamesi için Journals der Internationale Jurpisten-Kommission Bd. II Nr. 1 (Frühling . Sommer 1959) s. S v.d. bakını.

(10) Esen, adı geçen eser s. 166.

(11) Esen, adi geçen eser $s, 169$. 
tün kanunlardan önce gelir. Şayet devlet organları ve resmî merci. ler Anayasa huikümlerine sayg göstermekte iseler ve Anayasanın ihlâli halinde mahkeme bu ihlâli meydana getiren kanunu veya kararı, ya da emri bozabiliyorsa Anayasa üstünlïğui mevcuttur denebilir. Anayasamı her şeyden evvel Insan Haklarnn teminat altına almıștır. Insan Haklarının arasında en önemlilerinden birisi serbestçe tesirsiz haber alabilme imkânıdır. Basın, Radyo ve Televizyondan haber alabilme hürriyeti bunun neticesidir.»

Yukarıdan beri sıraladığımız temel mefhumlar Anayasa Mahkemesi kararlarında da ifadesini bulmuştur. Aşağıdaki ibareler Anayasa Mahkemesinin kararlarından aynen alınmıştır :

«Iptal dâvaları ile itiraz bașvurmalarnnda Anayasa Mahkem^sinin yaptığı şey, iki kanun hüikmiünden hangisinin uygulanacağını tayin etmektir. Burlardan biri Anayasa'da yer alan hüküm; aiğeri, herhangi bir kanunun hükmüdür. Bu durumda Anayasanın 8. maddesi ile tesbit edilmis bulunan genel esas gereğince, yani Anayasa üstünlüğ̈ü prensibine uygun olarak, kanun hükmünii değil, Anayasa hükmünü uygular (12). Hükmün tercihi için Anayasada bulunması kâfidir ve Anayasa üstünlüğ̈üiün korunması, ancak Anayasaya aykırı kanunun iptali ile mümkïndïr. (13) Anayasanın kurduğu devjet düzeni içinde Anayasa prensiplerinin korunması ve sistem de gedik açılmasına imkân verilmemesi şarttır. (14) Dolayısıyla Anayasadaki bir ilkeyi bozacak nitelikteki her hangi bir kanunî tedbir iptale uğrayacaktır.» "trısan hak ve hürriyetlerini, millî dayanışmayı, sosyal adaleti ve toplumun huzur ve refahını gero̧ekleştirmek ve teminat altına almak gerekleriyle tanımlanan demokratik hukuk devleti» (15), 11.10.1964 tarihli kararda kanun koyucunun kanunda üstünde be bozulmiyacak temel hukuk prensipleri ile bağlı olduğu jfade ediliyor. Kanunların «Anayasanın açık hüküumlerinden önce hukukun bütün bilinen ve bütün uygar memlekelerde kabul edilen prensiplerine uygun» olması şarttır (16). Parlamento kanun yaparken (genel hıkuk esasları) ile bağndır (17).

(12) Esen, Anayasa Mahkemesine göre Türk Anayasa hukuku anlayışı s. 37 ve d. Anayasa Mah. K. 377. 1964 Sayı 64/22 - 6454.

(13) Anayasa Mah. K. 11.1.1963 Sayı 64/124-64243.

(14) Anayasa Mah. K. 11.12.1964 Sayı 63/138 - 6471.

(15) Anayasa Mah. K. 5.3.1965 Sayı 63/171-65/13. Ayrica 28.5.1965, Sayı 65/ $12-65 / 33$ Kararı.

(16) Anayasa Mah. K. 22.12.1964, Say1 63/166-64/76.

(17) Anayasa Mah. K. 11.12.1964, Sayı 63/138.64/71. 
Hukuk devleti, «Insan haklanna saygı gösteren ve bu haklan koruyucu, adil bir hukuk düzeni kuran ve bunu devam ettirmeğe kendini zorunlu sayan ve bütïn faaliyetlerinde hukuka ve Anayasa. ya tyan bir Devlet» dir. (18)

\section{C) 1961 Anayasasının Genel Karakteri :}

Türkiyede son asrın siyasî olaylarını nazarı dikkate alan Kurucu Meclis, Anayasamızın başlangıç kısmında açıkca ifade edildiği üzere bir hïriyetler rejimi ve halk idaresi oian "Demokratik Hu kuk Devletini buitün hukukî ve sosyal temelleri ile kurmak" gaye siyle hareket ederek 1961 Anayasasını hazırlamıștır. Anayasa Komisyon raporunun genel gerekçesinde ayni fikir şöyle ifade edilmek. tedir: "Tasarıda Memleketimizin son ylllar içinde Anayasa inhiraf larnn önleyici ve hürriyetlerin teminatını teşkil edici tedbirler yer almıștır. Tasarı, rejimin demokrasiden inhiraf yapmaması, hürriyetjerin tecavüze uğramaması için, önce rejimin müdir prensipierini genel hükümler kısmırda zikretmiștir. Sonra da, bütün Anayasanın içinde yer allan esasların bir dokunulmazlık, bir illâl edilmezlik ilı tahkimi yoluna gidilmiștir. Bu tahkim Anayasanın üstünlüğü pren sibini kabul etmekle müeyyideye bağlanmıștır».

Hakikaten Anayasamız bu sözleri gerçek kılan bir muhtevada. dır. Mutlak hürriyet ve demokrasi anlayışı içinde temel prensipleri. kişilerin hak ve ödevlerini ve Cumhuriyetin temel kuruluşlarını tes. bit etmiş ve bunların dengesini kurmuştur. Rejimden ve Anayasa. dan inhiraflar kaydedilmemesi hürriyetlerin teminat altında bulurt. ması için siyasî iktidarın yetkilerini hudutlayan tedbirleri de ihnıal etmemiștir. Bu değerli eser, kuvvetler ve fonksiyonlar ayrulığı prensibi, çift meclis sistemini kabul etmiş, kazaî alanda Anayasa Mah. kemesi, Yüksek Hâkimler Kurulu, Danıştay gibi Yüksek Yargı or. ganlarınt, idarî alanda da Universite ve radyo idaresi gibi muhtar kuruluşları ihdas etmiştir. Bugün artık demokrasimiz hukukî yöon. den tam bir müesseseler dengesi nizamı içindedir ve rejimin sệâ. meti bu düzenin muhafazasındadır. Anayasamızın 8. maddesi Ana yasanın üstünlü̈̆̈̈ ve bağlayıcılığı esasını kabul suretiyle bu niza. mın hukukî müeyyidesini de tesis etmiş bulunmaktadır.

1961 Anayasasinda Radyo tdaresinin yeri ve bu idarenm Ana- yasaya müstenit nitelikleri şöyle özetlenebilir :

(18) Anayasa Mah. K. 11.10.1963, Sayn 63/124-63/243. 
Radyo idaresinin Anayasa içinde yer almasının başlica sebebi bir taraftan bu yayın vasitasının kudreti, diger taraftan radyoların. 27 Mayıs Ihtilâli ile tasfiye edilen dönemi içindeki kullanılış tarzı nin, demokratik düzen ve hürriyetler için zararlı olduğg kanaati ve buna benzer bir halin tekerrürünün önlenmesi arzusu olarak görül. mektedir. Filhakika Temsilciler Meclisi Anayasa Komisyonu rapo. runun genel gerekçesinde «Hürriyetler rejimi» kısmında, «Hürri. yetlerin Teminatı bașlı̆ğ altında;

"Tasarı, Hürriyetlerin ve Demokratik dïzenin teminatını, Üniversite, Radyo-Televizyon, ajans gibi muhtar muiesseselerin sosyal yapı içinde yer almasında görmüștür. Ayrıca... muhtar kamu tüzel - kişileri ihdası da hürriyetlerin ve demokratik düzenin teminat bü. türïnü tamamlayıcı sayılmıștır» denilmektedir.

Aynı fıkralar Anayasanın 121. maddesinin gerekçesinde de «Rad. yoların partizan tutumu ve partizan bir yayin vasitası haline geti. rilmesi, memleketimizde, uzun seneler ciddi bir huzursukluk konusu olmuştur. Bu sebeple, radyo muhtariyeti ve tarafsızlığı, Anayasa teminatı altına alınınak istenmiş̧tir» sözleriyle teyit edilmiș. tir.

Nihayet Anayasanin 121. maddesi: "Radyo ve Televizyon is. tasyonlarımın idaresi, özerk kamu tüzel kişiliği halinde, kanunla düzenlenir» hükmünü vaz etmiștir.

Buraya kadar siralananlar, sarih olarak gösteriyor ki 359 sayll Kanunla kurulmus bulunan Türkiye Rdyo-Televizyon Kurumu hakikatte demokratik düzenin, hürriyetlerin teminatı olarak, siyasi iktidann yetkisini tahhdit için Anayasa ile öngörülmüş, Anayasa teminatı altında bulunan bir özerkliğe sahip ve tarafsızlık esasla1’na göre yayın yapmakla görevli bir kamu kuruluşudur.

Hiç şüphesiz TRT'ye bu nitelikler, fonksiyonunu gerek siyasî iktidarın ve gerekse diğer siyasî kuvvetlerin her türlü tesir ve' müdahalesinden müteessir olmaksızın tarafsız bir şekilde ifa edebilmesi için tanımmıștır. Tarafsızlığın temini için alınan tedbirlerin başlica sebebi siyasî iktidardan duyulan endişedir. Bu itibarla TRT'nin özerkliği bir gaye değil, ve fakat gayeyi mümkün kllacak en ehemmiyetli vasitadır. Demokratik düzenin ve hürriyetlerin teminatı olarak öngörülmüştür. Bu mahiyetteki bir özerkliğin başta gelen icabl, hizmetlerin serbestçe organize edilmesi ve ihtiyaç. lara göre gerekli tedbirlerin serbestçe alınabilmesidir. Bu sebeple, 
Kuruluş görev ve kadro işlemnlerinin ve hizmetin gereği olan taz minatların, siyasî iktidarın tesiri altında bulunarak yapılması, yukardaki Anayasal gerçeklerin icaplarına aykırı bir idarî vesayetin vaz edildiğini göstermektedir. Bu gerçekler muvacehesinde kanunların tefṣirinde TRT'nin özerkliğini zedeleyici bir hattı hareketin Anayasayı ihlâl edeceği aşikârdır. Anayasanın iistünlüuğỉ ve bağlayıcılığı prensibi muvacehesinde böyle bir hale meydan vermemek hukuken zaruridir. Anayasanın 8. inci maddesi bu nizamin müeyyidesidir. TRT c̈zerkliği de Anayasa Mahkemesinin murakabesi altinda bir Anayasa ilkesidir.

Anayasamızın ana karekterinin Hukukun Ustüinlüğii prensibi olduğu, Devletin hukuka uyma mükellefiyetinin bundan doğdu. gunu, Arayasanın üstünlüğ̈u ilkesinin ise, Anayasa Mahkemesi tarafından kcrunmuş olduğunu görüiyoruz. 1961 Anayasası, bu pren. siplerin Türk hukukuna yerleşmemiş olmasindan, onlara olan ihtiyaçtan doğmuştur. Bu bakımdan Anayasa Mahkemesinin birinci görevi, Anayasanın "Ara Prensiplerini" korumaktır. 1961 Anayasa. sırın meydana geldiği günlerde Komisyon çalıșmalarında da Umu mî Hey'etteki konuşmalarda daima bu endişe kendisini göstermiş ve daima bu nokta üzerinde durulmuştur.

Radyo ve Televizyon idaresinin özerk bir Anayasa m;iesseses; olarak öngörülmesinin nedeni çok açıktır :

Anayasanın 19. maddessinde yer alan «düșünce hürriyeti» Ana. yaş Komisyonunun gerekçede belirtildìği gibi, «bütün ferdi hak. ların anasıdır». Bu temel hakkın gerçekten mevcudiyeti için şüp. hesiz, insanların medeniyetin, emirlerine verdiği buitïn araçlardan faydalanarık ve hiçbir kısıtlama veya engel olmaksızın serbestçe haberalma, kanaat edinme ve Kamu oyunun serbestçe oluşumu imkânlarnna sahip olması kaçınılmaz bir șarttır. Basın ve Yayın hür. riyetleri diğer hürriyetlerin teminatıdır. $O$ halde thürriyetler rejimi. ni kabul eder bir idare sisteminde, Radyo ve Televizyonun siyasi kuvvetlere karşı özerk olması, sistemin ve düßsüunce hürriyetlerinin mutlak şartıdır.

Düșünce hürriyetinin gereklerini tam olarak kabul eden bir idare sisteminde, radyo ve televizyon araçları vasıtasiyle serbestçe haber alma, serbestçe kanaat edinme ve kamı oyunun serbestçe olự̧unu, esaser: kaçınılmaz temel șartıdır (19). Nitekim Alman Yük-

(19) Bu Problemle ve Anayasanın 26 ve 121 nci maddelerinin tatbiki ile ilgili olarak Anayasa Mahkemesinde $967 / 37$ sayı ile bir dâvaya bu anda bakılmaktadır. 
sek Mahkemesi bu fikirden hareket ederek Anayasada bu cihet be. lirtilmediği halde Alman Radyo ve Televizyonlarının siyasî iktidar. lara karşı mutlak özerkliğine karar vermiştir (20). Bizde bu hükümAnayasada vardir.

Demek oluyor ki Radyo ve Televizyon idaresinin özerkliğinin nedeni, başta hürriyetlerin anası olan düşünce hürriyeti ve habes alma hürriyeti olmak üzere, bütün hürriyetlerin gerçekte tam ola. rak var olabilmeleri için gerekli teminatın sağlanmasıdır.

D) Acaba bu özerklikten ne anlayacağız? Bugün Türk huku kundaki anlamı nedir? Kanaatmuzca başvuracağımız en iyi kay. nak gene Anayasa Mahkememizin kararlarıdır.

«Özerklik, belli sıntrlar içerisinde serbestçe hareket edebilme. ye gerektirir. Özerk olan bir kuruluşun, kanunla belli sınırlar içə. risinde kalmak şartiyle, kendi hareketlerine hâkim olacak kaide. Jeri de yine kendisirin düzenlemesi gerekir». (21)

Burada Üniversitelerin ve TRT'nin Anayasadaki müşterek va. sıflarına ișaret etmek gerekecektir :

Her ikisi de «Özerk Kuruluşlar» ismini tașıyan ayn bölüm adı altında toplanmakla ana karekterleri eșittir. Her ikisinin de bu "Özerk» vasıflan yanułda "kamu tüzel kişileri» oldukları 120 ve 121 inci maddelerde ifade edilmiş ve «İdare»leri bu bünyeye bağ. lanmıștır.

$\mathrm{Bu}$ benzer bünyeden faydalanarak Anayasa Mahkemesinin 4.2.1966 gün ve E. $965 / 32$, K. $966 / 3$ sayll kararında bir başka yeri tekrar edebiliriz :

«Üniversiteler ilk önce, kanumun çizdiği sınırlar içerisinde (kendi kendisini yönetme) yetkisine sahip kamu tüzel kişileri ola. rak kurulmalıdırlar. Ancak Kanun koyucu, bu sınırları da diledigi şekilde ve dilediği derecede tayin edemez. Sinırları tayin ederken Anayasanın söz konusu ilkesini gözönünde tutmak ve (kendi kendisini yönetme) imkânmı Ùniversitelere sağlayacak surette hüküm. ler koymak zorunluluğundadır. Yasama yetkisini kullandığından

(20) Bak. yukarida not 7. Ayrica Anyasada zikredilmeyen hususlarm da Anayasa problemi olabileceği hakkında Anschütz Handbuch des deutschen Staatsrechts. Hrsg. von Anschütz und Thoma. Bd. I, s. 367.

(21) Yukarda Not 1. 
bahisle Üniversiteyi (kendi kendini yönetme) imkânından yoksun bırakacak şekilde sınır koyamaz».

Bu görüşler altında 359 sayılı Kanunun 47 nci maddesinin 2 nc bendini tetkik edielim. Anayasarnm 113. maddesi Îktisadî Devlet Te. şekküllerine kendi yönetmeliklerini bizzat yapmak yetkisini tanımıştır (22). 359 sayılı Kanuriun «Kurum hakkında İktisadî Derlet Teşekkülllerine uygulanan hüküimler uygulanır» şeklindeki 33. maddesi kendi yönetmeliklerini bizzat yapma yetkisinir Anayasanın bu hükmüi icabı clarak TRT Kurumu bakımından da doğduğunu tered. dütsüz ortaya koymaktadır. Bu gerçeğe rağmen tazminatlarla illgili yönetmeliğin 359 sayll Karumun 47. maddesine istinaden Devle1 Personel Dairesinin görïş̧inì, Maliye Bakanllğının mutabakatını almak gibi bir takim șartlara tabi tutulması hem Anayasa hem de müessesesinin hukukî statiusüne aykırı düșmektedir. Kaldı ki, 35 s sayıl Kanunun 47. maddesinin 2. fikrasında Personel Dairesinin görüusüüün de alınmasını gerektiren konu tazminat konusu değildir. Fikra şudur :

«Kurumun kadroları Yönetim Kurulu tarafından, Devlet Personel Dairesinin görüş̧ü alındıktan sonra Maliye Bakanlı̆̆ı ile an. laşmak suretiyle hazırlanıp. Turizm ve Tanıtma Bakanının onayı ile yaplacak bir yönetmelikte belirtilir». Bu maddede Devlet Personel Dairesinin görüşünün ve Maliye Bakanlığının mutabakatının alın. ması șart koøulan ve esasında Anayasanın 113. maddesine aykırı olan hal, sadece kadro mefhumuna münhasır kalmaktadır. Başka bir deyimle gerek Maliye Bakaniığı, gerekse Devlet PersoneI Dairesi ile anlaşma konusu olan hususun münhasıran «Kurumun Kadrola rı» tabirini kapsadığı bellidir. Şu halde kanun hükü̈mlerine; dogrn bir anlam verebilmek için kadro mefhumunun tayini gerekmekte dir.

«Bir kadro bir fert tarafından çalışma zamanı itibariyle tam veya kısmen belli vazifelerin icrasını ve bazı mes'uliyetlerin tașın masını tazammun eden münhal veya meşgul muayyen bir iş veya hizmettir's.

(22) b) Yönetmelikler,

Madde 113: Bakanlıklar ve kamu tüzel kişileri, kendi görev alanlarını ilgilendiren. kanunlarm ve tüzüklerin uygulanmasını sağlamak üzere ve bunlara aykırı olmamak şartıyla, yönetmelikler çıkarabilirler. Yönetmelikler Resmî Gazete ile yayinlanir. 
Leonard White'in bu tarifi (23) muhtelif hukuk eserlerinde yet almaktadır. Filhakika gerçekte kadro, hizmetin bölünmïs ve bir tek kişi tarafından ifa edilecek en ufak parçasından başka birşey de. ğildir. Gerek hukuk ilminde gerekse hukuk tatbikatında kadro doğru olarak ancak, bu anlanda kullanılır. Münhal kadro, dolu kadto tertiplenmesi, kadro teçhizatı, kadro aktarmaları, kadronun mahfuz tutulması gibi tedbirler her azman için münhal hizmet, dolu hizmet, hizmet ücreti, hizmet borçlarmn tertiplenmesi, hiz. wetin gerektirdiği teçhizatı, hizmtet aktarılması, hizmetin mahfuz tutulması anlamından bașka bir mâna tașmaz. Hukuk nazariyeı ve tatbikatının bu 1 șı̆̆ altında 47. maddedeki «Kurumun Kadro. ları» tabiri mânalandırılmakta görülen gerçek kurumun hizmet ünitelerinden ibarettir.

Demek oluyor ki, 47. maddenin 2. numaral hükmü gereğince, Devlet Perconel Dairesinin görüşünün alınmasını ve Maliye Bakan. Iığı ile anlaşmayı gerektiren husus hizmetirn tertiplenmesi hususun. dan ibarettir.

Kadroların tesbiti özerklikle ilgili en önemli konulardan biridir. Kadro ihdası demek hizmetin kurulması demektir. Bir misâl ile jurumu açılıyalım: TRT idaresi haber ve sözlü yayınlarını geniş. letmek istese tunun için kadrolar ihdasa meobur olur. Bu kadro. jarın verilmesi siyasî iktidarın elinde olsa bunları vermemek yolu ile TRT'nin ișleyiçirıe doğrudan doğruya tesir edebilir. TRT idare. si son zamaniarda Mersin, Diyarbakır, Erzurum verici istasyonla. rinı işletmeye almak istemiş, bunlar için gerekli kadroları elde edememiştir. Bu yolla siyaŝ̂ iktidar istediği yerde radyo istasyonu kurmak ve istediği neşriyat ${ }_{1}$ - ora ait kadroyu vermek suretiyle. yaptırmak imkânuna malik olur.

Anayasa mahkemesi (24) hizmet ve kadro arasmdaki ilgiyi șu șekilde ifade etmiştir : Bir kurumun kuruluşu deyince her şeyden önce o kurumu yuiruitecek' personele ait kadrolar hatıra gelir. Zira kurumun temelireden çatısına kadar bütün örgütünü bu kadrolar teşkil eder. Personel kadroları mevcut olmayan bir kurum, henüz kuruluş haline geçmemiş demektir. Şu halde bir kurumu çalıṣır hale getirecek olan Personel kadrolarının, en küuçüğinden en bui.

(23) Leonard White, Introduction to the Study of Public Administration. s. 1954. Türkçe Tercümesi : Àmme Idaresine Giriş, Ank. 1957. s. 65.

(24) 4.2 .1966 gün ve E. 65/32 K. 66/3 kararn. 
yüğüne kadar, bütününü kuruluştan ayrı düş̧ünmeğe imkân yok. tur.

"Bir kurumun işleyişi» kavramının ise, söz konusu Personel kadrolarının görevlerinin ne olduğunu, kurumun amacına ulaşmak için bu görevlerin ne suretle ve hangi yollarla yerine getirileceği. ni, birbirleriyle olan ilișkilerini kapsadığını izaha hacet yoktur.

«Bir kurulus, onu yürütecek personele ait kadrolardan mey. dana gelir. Kadro, kuruluşunun genel hizmet plânı içinde belli bir görev yerini temsil eder. Bu bakımdan bir kadro tesbit edilirken, cnun genel hizmet plânı içindeki yerinin, yani özel görevinin, bu görev karşılığında verilecek ücretin birlikte belirtilmesi zorunlu. dur".

Özerklik hizmetin bizzat tanzimi demektir. Eğer kadrolar siyasî kuruluşlarla beraber yapılırsa hizmetin yalnızca tanzimi müm. kün olmaz ve netice itibariyle özerklik sona erer. 440 sayılı kanunda bile kadroların tanzimi İktisadî Devlet Teşekküllerine verilmiş. ken TRT de bunun, Anayasa teminatma rağmer, verilmemiş, olmașinı izaha imkân yokitur.

Görülïyor ki, 359 saylı Kanunun 47. maddesinin «... Devlet Personel Dairesinin görüşü alındıktan sonra Maliye Bakanlı̆̆ı ile anlaşmak suretiyle hazırlanıp, Turizm ve Tanıtma Bakanliğının onayiyle..." ibaresi Anayasaya aykırıdır. Filhakika yukarıda gös. terdiğimiz gibi Anayasamıda Merkezi †dareden ayrı olarak Muhtar Idare Kurulușları yer almıștır. TRT Kurumu 359 sayllı Kanın la özerk olarak kurulmuş bir Kanu Tüzel Kişiligidir. TRT'ye özark. lik tanınmasmm r.edeni, Anayasamızın 121. ci maddesinin gerekçe sinde sarahaten belirlidir. Demokratik rejimin ve hürriyetlerin te minat clarak kabul olunan ve Arayasamm teminatı altında bulu nan Radyo-Televizyon hizmetlerinin ifasında siyasî iktidarların baskılarından masun kilınnak ìzere, merkezî idare sistemi içinden çßkanlıp, muhtar bir idare olarak kurulmuştur. Anayasa yapıcısı. inın siyasî iktidarların baskısı hususundaki ciddi endişesini hakh kılacak hüküm maalesef 47 , ci maddede yerini bulmuștur.

Anayasann 113. cii maddesi geregince ve 440 sayıl Kanunla özerk olmayan kamı tüzel kişileriinin dahi kendi yönetmeliklerinj yapmakta muhtar olduklar hukuk düzeni içinde, Anayasa ile özerk olarak kurulması öngörülmïș ve Anayasa teminatı altında bulunan özerk TRT, 47. ci maddede hükmü ile kendi yönetmeligini yapma 
yetkisini siyasî iktidarın emri altında Merkezî Idarenin bir kurulùşu ile paylașmak zorunluluğunda bırakılmıștır. Nitekim, Kanunda vazminat alacaklar arasında açıkca gösterilmis "Organizasyon» hizmet kadroları TRT kurumunun israrlı taleplerine rağmen Maliye Bakarilı̆̆ının mutabakatı olmadı̆̆ı için, tazminat yönetmeliğinde yer almamıștır. 359 sayılı Kanunun 47. ci maddesi Kurumu, kadro larına ait yönetmeliğin hazırlanması surasında merkezi idare siste. mi içinde ve siyasî iktidarın pək tabi olarak emri altında bulunan Maliye Bakanlığ ile müsterek irade beyanına mecbur tutmakla, Anayasanın kurumun özerkliği hususunda koyduğu hükme aykırı bulurmaktadir. Zira TRT'nin özerk olarak kurulmasındaki esas amaç, düşünce ve haber alıp serbestçe kanaat edinme hürriyetinj siyasî iktidarlar karşısında teminat altına almaktır. Oysa ki özerk bir kiưuluşun hizmet kadrolar ile bu hizmetin özelliği hususunda ki takdir yetkisini bir başka idare ile, yani siyasî iktidarn emri altunda bulunan Maliye Bakanlığı ile paylaşma zorunluğu, teminat altında bulunan bir c̈zerk idareyi, dolaylı bir yolla siyasî iktidarın baskısı altına sokmak olmuștur.

TRT Kurumunun ÖZERK bir kamu tüzel kişiliği niteliğinde bulunduğunu Anayasaya ve kuruluș yasasına derc etmek yeterli de. ǧildir. Kurum hakkında uygulanan Kanun hükümleri ve sair mevzuat, kurumun bu özerkliğini zedeleyici veya ortadan kaldırıcı nite likte ise Anayasanın üstünlüğ̈u prensibi ile birlikte diğer maddeleri de ihlâl edilmiş olur (25). Anayasanın 121. ci maddesinde «RADYO ve TELEVIZYON ISTASYONLARININ IDARESI ÖZERK KAMU TÜZEL KIŞİLIĞİ HALINDE, KANUNLA DÜZENLENIR» denilmektedir. Her ne kadar bu madde ile TRT idaresinin Özerk Ka. mı Tüzel Kişiliği halinde düzenlenmesi yetkisi yasama organına veijlmiş ise de Anayasa Mahkemesinin de belirttiğ gibi 112 nci mad. tenin scn fıkrasında öngörülen «kanunla veya kanunun açıkça verdiği yetkiye dayanılarak" kurulacağı belirtilen kamu tüzel kişilerini ihtiyaca göre dilediği şekilde kurmağa ve ora dilediği görev ve yetkiyi vermeğe kanun koyucu mezum bulunduğu halde, Anayasanın 121 inci maddesi TRT bakımından kanun koyucuya özerklik ve tarafsızlık ilkelerine riayet mecburiyetini Anayasa kuralları ha. inde emretmiştir. Yasama yetkisine sahip Meclisler dahi Anayasa. nın âmir hükmiu karşısında TRT'nin özerkliğine uygun bir hare

(25) Esen,adı geçen eser, s. 123 v.d. "Devletin hukuka uyma mükellefiyeti» bahsi. Ayrica Anschütz, a.g. eser. I, s. 373 v.d. 
ket tarzı içinde bulunmaya ve kanunları bu özerkliğe uygun tarz da tanzim etmeye ve kanunlarm maddelerini dahi bu açıdan yo. rumlamaya mecburdur. Aksi hal yukarıda da gösterdiğimiz gibi Anayasanın üstünlü̈ği prensibini vaz eden 8 inci maddesine aykırı olur.

Nitekim, Danıștay, Turizm ve Tanıtma Bakanlığının, TRT'yi denetlemek istemi karşısında ittihaz ettiği kararı (26) ile TRT'nin üzerkliğini bu anlayış içinde yorumlayarak, Bakanlı̆gn kurum üze rinde hiyerarşik bir üstünlüğ̈̈ bulunmadığı ve vesayet makamı da olmadığı hususunu kabul ile, TRT'yi denetleyemeyeceğine hükmetmiştir.

E) TRT nin özerkliğinin șumülià ve gayesi nedir?

Bir idarenin özerkliğinin yasalara derc edilmiş olması kâfi de ğildir. Bu özerkliğin fiilen varlığını sağlayacak ayrı bir düzenleme. ye ihtiyaç vardır. Alıran tedbirler bunu gerçekleștiremiyorsa, özerklikten, Anayasa Müesseselerinden bahsetmeye imkân yoktur. Bu ise 1961 Anayasasi ile kunulnak istenen denokratik hukuk devleti ilkesini temel müesseselerinden malhrum kılmak anlamını taşıyacaktır (27). Anayasanın özerk müesseseleri bu gün kendilerini kabul ettirebilme çabası içindedir. Bu arada TRT'nin durumu daha güç görünüiyor. Zira Anayasanın 120 nci maddesi Universiteye ida. ii ve bilimsel özerklik tanımışken, 121 inci madde TRT'ye daha geniş bir özerklik tanımıştır.

Bilindiği gibi Anayasamı luwetler ve fonksiyonlar ayrllı̆ı prensibini kabul etmigtir. Fonksiyonu bir yürütme görevi olan radyo idaresi, Anayasanın Cumhuriyetin temel kuruluşu kismında ve «idare» bölümünde özerk bir kuruluş olarak yer almaktadır.

Bu hal bir hizmet ademi merkeziyeti karekteri arzeder. Yürütmeden koparılmış olan bu hizmeti Anayasal mertebede bir bölünüş̧ olarak vasıflandırınak daha dogru olacaktır. Anayasal kuru. luşların niteliği hizmet ademi merkeziyetinden ziyade fonksiyon. lar ayrılı̆̆ bünyessinde beliren tali ayrım karekterini taşır. (28)

(26) Danıştay 3. D. 8.4.1965 gün ve E. 65/8, K. 65/7 Kararı.

(27) Birinci Cihan Harbinden sonra aynı problemlerin Almanyadaki durumu için Bausch, Der Rundfunk im Politischen Kräftespiel der Weimarer Republik. 1956, Sayfa 55 v.d.; Sayfa 102 ve 199'a bakınz.

(28) Esen, Anayasa Mahkemesine göre Türk Anayasa Hukuku anlayışı s. 42 v.d. 
Bu durumda Radyo Televizyon idaresinin özerkliğinin nite Iikleri şöyle ifade edilebilir :

Bu özerklik tüm hürriyetlerin teminatıdır. Fonksiyonlar ayrı. lığı prensibi içinde beliren bir tali bölünüs neticesi vïcut bulmak: tadır. Bu özerklik Anayasanın teminatı ve Anayasa Mahkemesinin denetimi altındadır. Anayasanın cevaz vermediği hallende kısıtla. namaz. Aksi halde Anayasanın kurduğu sistemde gedik açılmıs ola. rak ve tüm hürriyetlerin zedelenmesine imkân verecek bir teminal zayiflaması vücut bulacaktır.

Anayasa 120. maddesi ile Üniversitelere sadece bilimsel ve ida dî özerklik tanırken Radyo ve Televizyon idaresine "Radyo ve Te. levizyon idaresi, özerk kamu tüzel kişiliğgi halinde kanunla düzen. lenir» demek suretiyle Radyo ve Televizyon idarelerine evvelâ ka. mu tüzel kişiliği ve bu tüzel kişiliğe her sahada özerklik tanımıș. tır. Bu, ifa edilecek hizmetin gerektirdiği bir durumdur. Çünküi siyasî iktidara karşı insan haklannın teminatı olarak görev ya. par (29). Radyo ve Televizyor: ile yaym yapacak bir müessesenin özerklik ihtiyacı faaliyetlerinin bütün sahaların kapsar. Kısmı ¡̈zerklik de bahis konusu olamaz. Hizmetinin mahiyeti, kısmî özerk. likle arzulanan neticenin istihsaline müsait degildir.

Almanya'da Profesör Maunz'un 1963 yllında Bavyera Hükûme tine verdiği raporda belirttiği gibi: «Radyonun özgürlük veya özerk. liği üç kısımdan teşekkül eder.

1. Programlann serbestçe tanzimi

2. Yayın tesislerinde serbestçe tasarruf

3. İktisadî ve malî özgürliik.

Siyasî iktidarm tunlardan herhangi biri üzerine yapacağ müda. hale, özerkliği zedeler ve serbestçe haber alma, kanaat edinme hak: larını ve kamu oyunun serbestçe oluşumunu zarara uğratır. Eğer Radyo idareleri, bütçeleri üzerinde her türlü sarfiyatta serbestçe tasarruf yetkisine sahip olmazlarsa, teşkilâtlarını serbestçe kura. mazlarsa, senbestçe program tanzimi münküin olamaz».

TRT'nin genel yaym ilkeleri şu șekilde tesbit edilmiștir. TRT Kurumu yayınla ilgili görevlerini gerçekleştirirken :

a - Mevzuat hükümleri

(29) Pohle, Der Rundfunk als Instrument der Politik. 1955 s. 42 v.d, 
b - Mevzuat hükiülerinden çıkan ve kamu yayın organı niteliģinin gereklilik ve sorumluluğunun sonucu olan ilkeleri esas olarak alır.

Mevzuattan doğan yayın ilkeleri şunlardır :

Anayasamzın başlangıcinda, temel hak ve ödevler bölümlerinde ve öteki maddelerinde yer almış olan esaslar yayın ilkelerinin temelidir.

«Kurum yayınlarında Türk Ulusunun kaderde, kıvançta, tasada ortak, bölünmez bir bütün olduğu ilkesini önernle uygular. Türk Milliyetçiliğinin hizmetindedir, Türk Milletinin dünya millèleri ailesinin eşit haklara sahip şerefli bir üyesi olarak millí birlik ruhu içinde yüceltmeyi amaç bilir. İnsan hak ve hürrịyetleri, millî dayanışma, sosyal adalet, fertlerin ve toplumun huzur ve refahı için çalşsır. Cumhuriyete, onun niteliklerine, devletin bütünlüğüne milletin eğemenligine tam bir inançla hizmet eder. Anayasanın üstünlüğü ve devlet onganlarının yetkileri konusunda hassas olmayı görev bilir. Kișilerin hak ve ödevlerine saygilidır, bunların benim. setici çabaların hizmetindedir. Türk toplumu çă̆daş uygarlı dï. zeninde lâylk oldư̆u yeri alması amacını güden Atatürk devrimlerini şaşmaz ülkü olarak benimser. Seçim Kanunlarındaki hüküm. ler saklı kalmak üzere tam bir tarafsızlık içinde halka hizmet eder; Haberlerin dogru olmasına önem verir, programların fikir, sanat, millî eğitim, halk eğitimi, toplum kalkınması bakımlarından yeter. li olmasını sağlamağa çalışır.

Kamu yayın organı niteliğinin gereklilik ve sorumluluğundan doğan yayın ilkeleri : Kurum, yukarıda belirtilen ilkelerin ișı̆ı al. tında bir kamu yayın organı olmasının sonucu olarak, aşağıda be lirtilen esasları da kabul etmiştir: Toplum içinde huzur ve kardes. lik duygusu yaratmak; güven ve inanç içinde çalışmayı aksatacak âciz, karamsarlık, bıkkınlık ve umatsuzluk yaratacak, moral bozu. cu, yıldırıcı veya nezakete aykırı yayınlara yer vermernek; Yaşama sevincini, uyanıklığı, birbirini sevmeyi, çalıșma şevkini artırmayı hedef tutmak; Yurt gerçeklerini saklamamak, bunları bilimsel ve objektif olarak yansıtmak; Ulusal çıkarları gözetmek; Ulusun kendi âlı̧̧ma gücüne ve yurdun ekonomik imkânlarına güvenini des. teklemek; Devlet ile milletin işbirliğini săglamak; Ulusu refaha ulaştıracak her türlü çabaları desteklemek Plânlı çalıșmayı des. teklemek. 
Bütün bu hedeflere ulaşabilmek için her şeyden önce milletin ve Anayasa rejiminin hizmetinde bulunduğunu duyurmak, milletin görevine sahip olmaya çalışmak kurumun esas amacı olacak:Ir» (30).

Bu ilkeler ancak özerklikle gerçekleștirilebilir. Esasen özerk kuruluş idarî vesayete tabi olmayan kuruluștur. Bu itibarla Anayasanın tanıdığı özerklik TRT'nin bïtün çalıșma sahalarım kapsar ve bu sa. haya bask1 yapmak ihtimal veya istidadında olan bütün teşekkül. lerin, hususiyle iktidarın ve onun emrinde olan idarelerin müdaha. lelerine imkâr: vermeye manidir.

TRT'nin özerkliğinden Anayasanın gözönünde tuttuğu gaye IRT'in insan haklarmın teminat müessesesi olması, serbestçe ha. ber alma, serbestçe kanaat edinme ve kamu oyunun serbestçe olu. sumu hak ve hürriyetlerinin siyasî kuvvetler tarafından zedelen. memesidir. TRT özerkliğini savunurken, siyasî kuvvetlerin insan hakların zedeleyecekleri bir sahaya girmesini önler. Bu hulûl her ne şekilde vuku bulursa, neticede siyasî iktidar kendisine Anayasa le yasaklanmıș bir sahaya girmiș olacaktır. Özerklik malî denetim bahanesiyle de dolaylı surette ihlâl edilmiş olacaktır. Bu şart. lar altında Anayasanın öngördüğü haklar konusunda TRT'nin te. miriat müessesesi görevini yapmaya imkân kalmayacak, Radyo ve relevizyon araçlarından istifade ederek serbestçe haber alma, ser. bestçe kanaat edinme ve kamu oyunun serbestçe oluşumu hak ve hürriyetleri zedelenecektir. TRT'nin esas fonksiyonu her türlü baskıdan azade olarak tarafsız yayın yapmaktır. Bunun icrası özel bir (güvenlik) ister. Muhtar bir kuruluşun ihtiyacı olan yetkilerin ıümünün bizzat kullanılmasını zaruri klar. İktidarın, insan hak ve hürriyetlerini daima gözetmediği malûmdur.

TRT özerkliğinin mahiyeti bu șekilde anlaşıldıktan sonra, bunun bu günkü idare içinde umumî bir kabul görmemesinin, anla yıșla karş̧lanmayışının bir soru olarak ortaya gelmemesine imkân voktur. Bu özerklik memleketimiz için yenidir. Universite özerk liği nasıl 1946 senesinde kabul edildikten sonra bir yı̆ın çekişme lere sebebiyet verdi ise, TRT özerkliği de bugün ayn safhaları ya¡amaktadır. Üniversitelerde özerklik 15 senelik bir «alıșma» dev

(30) TRT. yayın ilkeleri için Köttgen, Die Kulturpflege und der Bund in Staats und Verwaltungswissenschaftliche Beiträge. 1957 s. 183 v.d. Staats und Verwaltungswissenschaftliche Beiträge. 1957 s. 183 v.d. bakınız. 
resinden sonra sikıntılarını atlatmış̧ır. TRT özerkliğinin de bu günki devri bir «alışma» devridir. Bu «alışma»nın münkün oldu ğu kadar çabuk gerçekleșmesi ve TRT özerklï̆inin Anayasa için deki mahiyeti ile kabullenmesi temenni edilir. Beşeriyet tarihinds yeni fikirlere alıșmanın daima güiç olduğu görülür. Dinlerin . ken dilerini kabul ettirmeleri çok defa 4.5 asır sürmüştür. Fransız İh tilâlinin fikirleri hakikî mânasında bir asır sonra umumî kabuł görmüştür. Türkiye bugün 1923 de memleketimize gelen garp fi kirlerinin kabullenilmesi ve onlara karș direnmenin halâ çekişme î içindir. TRT özerkliğinin anlaşılmasındakì güçlük de bunlarla ilgilidir.

359 sayll Kanunun, aslinda problemleri bulunmayan bir ka ilun olmas1 gerekirdi. Kanunun Anayasanın 121 inci maddesinin hükmüne uygun bir metin olacaktı. Anayasanın özerklik konusun daki ana prensipleri pek tabii olarak kanunda yeniden ifadesin bulacak ve özerklik bakımından Anayasaya aykırı bir hïküm bu lunmıyacaktı. Dâvamızın konusu olan "Yönetmelik yapma» yetki. sinin de özerklik prensibine uygun tanzim edilmiş olması gerekir di. Kısa ifadesi ile, Anayasanın 121 inci maddesi 359 sayıl Kanı nun tamamina hâkim ana prensip olarak her madde kendisini göstermeli idi.

Acaba 359 saylı Kanun böyle midir, iç durumu nedir? Kanu. nun birinci maddesinde "Türkiye Radyo-Televizyon Kurumu adiy. la, tüzel kişiliğe sahip özerk bir kamu iktisadî teșebbüsü kurul. muştur» denildikten sonra ikinci maddesinde (a) bendinde - Türkiye Radyo-Televizyon Kurumunun görevleri arasinda - «radyo vt televizyonla haber hizmetlerini görmek... yurdu içeride ve dişarı. da tanıtıcı, yeterli, doğru ve tarafsız yayın yapmak» denmektedir.

Anayasamızı 26 ve 121 inci maddeleri ile, yayın fonksiyonu. nu tam, birtaraflıkla yapacak bir Radyo-Televizyon idaresi kurulması için gerekli esasları tesbit etmiştir. 359 saylı Kanunun Hükûmet tasarısının gerekçesinde belirtildiği üzere «Anayasadan doĞan fiilî ve hukukî zorunluluklara» dayanılarak hazırlanmış ve bi. rinci maddesinde Anayasa ile öngörülen özerklik teyid edilmiş, kurumun en yükisek karar ve yönetim organının Yönetim Kurulu o]duğu 3. madde ile belirtildikten sonra Kurumun Yönetim Kurulunun aldığ kararlar çerçevesinde ve onun gözetimi altında Genel Müdür tarafından yönetileceği 2. frkrada belirtilmek suretiyle yönetim ve gözetim görevlerini tayin etmiș, Kurumun tarafsızhğını ve demokratik esaslara uygunluğunu sağlamak amacı ile Yönetim 
Kurulunun teşekkülünde 4. madde ile seçim esası kabul edilmiş ve 5 yll olarak tesbit edien hizmet süresi içinde seçimle gelen altı azanın görevlerinden hiçbir suretle uzaklaştırılamıyacağı öngörül. müşs, 9. madde ile Genel Müdürün tayin ve işten el çektirilmesinde Yönetim Kurulu ile Hükúmetin iradelerinin birleșmesi esası kabul edilmiş ve yaynnların tesbitinde özerklik esasları gözönünde tutu. larak hükümler getirilmiştir.

Kanunun diğer kısımlar1 ve bilhassa hizmetlerin düzenlenomesi ile ilgili yönetmelikler ve bütçe konusunda Turizm ve Tanitma Bakanına bir yetki tanındığ görülmektedir (31). Ancak 359 saylı Kanunun Hükûmet Tasarısı gerekçesinin 7. frkrasında mevcut «Yü. rütme organı ile Kurumun münasebeti dïzenlenirken yürütme orga. nına kurum üzerinde hiyerarşik bir merci yetkisi verilmemiș, Kurum; Karunda yazil muayyen hallerde, bir kamu tüzel kişisi olma. $\mathrm{s}_{1}$ ve hizmetin bir âmme hizmeti bulunması gözönünde tutularak organlarmmn seçimi... yatırmlar... hizmetinin dïzenlenmesi baki. mından yürütme organı ile irtibat makamı olarak Basın Yayın ve Turizm Bakanlığına bağlanmıștır» şeklindeki izahattan da anlașıla. cağı üzere, Kurumun Basın Yayın ve Turizm Bakanlığı ile ilgilen. dirilmesinin sebebi, yürütme organı ile irtibatının sağlanabilmesin den ibaret olup, Anayasa ile kurulmuş özel ve özerk bir kamu ikti sadî teșebbüsü olduğu noktasmdan hareketle Kurum üzerinde yürütme organına hiyerarşik bir merci yetkisi tanınmamıştır.

Kurumun denetlenmesi konusunda ise; iç denetim bakımından čözetimin, 359 sayll Kanunun "Kurum Yönetim Kurulunun aldığı kararlar çerçevesinde ve onun gözetimi altında Genel Müdürü tarafından yönetilir» diyen 3. maddesinin ikinci fikrası hükmü gers. ğince kendi iç bünyesinde ve kendi organları ile yapılması; dış delietimi bakımından da «Kurum Yüksek Denetleme Kurulunun de netimine tabidir. Turizm ve Tanıtma Bakanı, Kurumla ilgili olarak belli bir hususun incelenmesini Yüksek Denetleme Kurulundan is teyebilir» diyen 34. maddesi hükmü gereğince Yüksek Denetleme Kurulu tarafindan yapılması esası vaz edilmiș ve nihayet 12.5.1964 tarihli ve 468 sayllı «Kamu tktisadî Teșebbüslerinin Türkiye Büyüik Millet Meclisince Denetlenmesinin Düzenlenmesi hakkındaki Ka. nun» gereğince bu denetimin Türkiye Büyük Millet Meclisinde sonuçlandınlması öngörülınek suretiyle Anayasanın emrettiği esas.

(31) 359 saylı Türkiye Radyo Televizyon Kurumu Kanunu Madde 28, 33 ve 47. 
!ara uygunluğu tereddüidü mucip olan özel bir denetim sistemine tabi tutulmuștur.

Ord. Prof. Sıddık Sami Onar «Anayasanın Radyo ve Televizyon idaresini Anayasa esaslarına bağlanmasının sebeplerini belirttikten sonra "Bü bakımdan radyonun teknik mahiyeti itibariyle bir hizmet ademi merkeziyeti teșkilâtı haline getirimesi de kâfi gelmemiş, bu kurumun hiyerarşi ve hatta idarî vesayet dışında kalan Ana. yasa himayesinde özerk bir kuruluş haline getirilmesine lüzum ha. sıi olmuştur» diyerek, bir kamu iktisadî teșebbuisì olan TRT'nin diğer hizmet ademi merkeziyeti kuruluşlarından farkh tarafsız ve müstakil, ëzerk bir müessese olduğuna işaret etmekte ve «...̈̈zerk. liği Anayasa ile sağlanmıș ve bu bakımdan bir Bakanlığın hizmet ademi merkeziyeti esasma göre sadeca tüzel kișiliği haiz ve kat. ma büitçeli bir teşkilâtı olmayıp, Hükûmet dıșında kalan ve organı rnuhtelif müesseselerden seçilen bir özerk kuruluștur» ve yine "görülüyor ki Radyo ve Televizyon Kurumu... her türlü hiyerarşi ve idarî vesayet denetimi dişında, Anayasa ve Kanunun verdiği gö. revi kendi kanısına ve görüșïne göre yapabilen müstakil ve taraf. siz, c̈zgür ve özerk bir organa sahiptir» șeklindeki Kurumun Anayasal özerkliğinin mahiyetini açıklamaktadır. (32)

Anayasamn Kurucu Mecliste görüșülmesi sarasında Anayasa Komisyon š̈zcüsü Prof. Hıfzı Veldet Velidedeoğlu'nun özerk ku. rulușlar hakkında «özenk, kendi kendini idare eden demektir» şeklindeki beyanı veçhile, hukukî mahiyeti bakımından kendi kendini idare etmeyi istihdaf eden özerklik, Anayasanın tayin ettiğ belli sinırları içinde serbestçe hareket edebilmeyi gerektirir. Bu itibarla, Anayasanm 121. maddesi ile özerkliği, teminat altına all. nan ve 359 saylı kanunu gereğince merkezî idare hiyerarşisi ve idarî vesayet denetimi dışında kalan bir statü dahilinde özerk bir kurulus olan TRT Kurumu, yukarıda belirtildiği üzere murakabe bakimından da kendi özel Kanununun hükümerine tabidir.

TRT üzerinde Turizm ve Tanıtma Bakaniığının hiyerarşik ve Maliye Bakanlığının bir malî denetimi bulunup bulunmadığı hususu TRT ile ilgili Bakanlıklar arașında uyuşmazlık konusu olmuș, Danıştay kanunî çöziùm tarzının ne olduğunu kararlarla ortaya koymuştur.

(32) S. S. Onar. Ídare Hukukunun Umumî Esasları, 1967 Baskısı s, 887 ve devami. 
Danıştay 3 üncii Dairesi 1 Haziran 1965 tarihinde verdiği kararında şu esasları tesbit etmiştir: «Her ne kadar 359 sayılı TRT Kanununun 33 üncii maddesi TRT'nin de 440 sayılı Kanunun genel hükümlerine bağlı olacağını açıklamışsa da, bu bağlılık kayıtsız. șartsız olmayıp, TRT Kanunundaki özel hükümleri saklı tutmak kaydiyle sınırlandırılmıștır. Bu itibarla 440 sayılı Kanun hüküm. lerinin TRT hakkında uygulanabilmesi için 359 sayılı Kanundakj jzel hüküimlerle aralarındaki her hangi bir çatışma olmaması lâ. "ım gelir. Bir bașka deyimie bu hüküimler ancak 359 sayılı Kanundaki özel hükümlerin verdiği cevaz ve imkân nisbetinde TRT bakımından hüküm ve değer ifade eder. 359 sayıl Kanunun 34 üncü maddesi 440 sayll Kanunun 9 uncu maddesindeki, Bakanın, teșek. külïn çalışmaların gözetlemek ve hesap ve işlemlerini teftiş ve isabında tahkike tabi tutmak yetkileriyle çatıșma halindedir. Bu üzel hüküm 359 sayl1 Kanumun 33 üncü maddesindeki hüküimle saklı tutulduğundan, Bakanlığın bu konuda yetkisi yoktur.» Danıstay șu duruma göre: "Turizm ve Tanıtma Bakanlığının TRT'de teftiş ve tahkike yetkili bulunmadığı mütalaa edilmiştir» demek. tedir.

Yine Danıştay 3 üncü Dairesi 8 Nisan 1965 tarihinde oybirli. ğiyle verdiği başka kararmda yukardaki neticeye șu gerekçeyle var. mıștır: "Anayasamızda «özerk kuruluşlar» matlabı altında Üni sersitelerden sonra yer alan «Radyo Televizyon Idaresi ve Haber Ajansları» başlıkl 121 inci maddesi hükmü ve buna dayanılarak çkarlan 359 sayılı TRT Kanununun hükümleri ve bumların gerekçeleri birlikte mütalâa edilerek 359 sayılı Kanunun 33 ünciu mad. desiyle Iktisadî Devlet Teşekküllerine uygulanan genel hükümlere yapılan atfın 440 sayılı Kanunun yalnızca malî hükümleriyle ilgilj bulunduğu ve Tanıtma Bakanlığının ancak bu hükümlerde bahis konusu hususlarda ilgili Bakanltk olarak yetkili olduğu anlaşılmıs ve bu itibarla Anayasayla özerk bir müessese haine getirilmiș bulunan TRT Kurumunun izerinde $\mathbf{4 4 0}$ sayll Kanunun tktisadî Dev. lct Teşekkülleri ve müiesseselerinin yönetimi ile ilgili 9 uncu mad. desinin adı geçen Kurum hakkında uygulanamıyacağını ve binnetice Turizm ve Tanıtma Bakanlığının 440 sayll Kanunun 9 uncu maddesine istinaden TRT kurumunun (hesap ve işlemlerinin teftis€, tahkike ve tesbite) yetkisi bulunmadığına... oybirliğiyle karar verilmiștir».

TRT Kurumunun Maliye Müfettişlerinin teftişine tabi olup ol. ınyacağı yönünden Maliye Bakanlığı ile TRT Kurumu arasında do- 
ğan bir uyuş̧mazlığı çözümleyen Danıştay 1 inci Dairesi, 1 Haziran 1967 tarihinde oybirliğiyle vendið̆i ve Danıştay Genel Kurulu tarafından 15 haziran $196 \%$ tarihinde cnaylanan kararnda "Kurumun, Ba. sin Yayın ve Turizm Bakanlı̆̆ıla ilgilendirilmesinin sebebi Yürü̈tme Organı ile irtibatının sağlanabilmesinden ibaret olup Anayasay. la kurulmuş özel ve özerk bir kamu iktisadî teșebbüsü noktasından hareketle Kurum üzerinde Yürütme Organına hiyerarşik bir mercỉ yetkisi tanınmamıștır. Kurunun denetlenmesi konusunda ise: İ̧ Denetim bakımmndan gözetiminin kendi iç bünyesinde ve kendi or. ganlarıyla yapılması, Dıs denetimi bakımmdan 34 üncü maddesi hükmü gereğince yapılması esası vaz'edilmiş ve nihayet 12 Mayıs 1964 tarihli ve 468 sayılı "Kamu lktisadî Teşebbüislerinin TBMM'ce denetlenmesinin düzenlenmesi hakkındaki Kanun» gereğince bu denetiminin TBMM'de sonuçlandırılması öngörüilmek suretiyle Anayasanın emrettiği esaslara uygun olarak Kurum özel bir denetim sistemine tabi tutulmuștur... Anayasanın 121 inci maddesiyle özerkliği teminat altına alınan ve 359 sayılı özel Kanun gereğince menkezî idare hiyerarşisi ve idarî vesayet denetimi dışında kalan bir statüi dahilinde, özerk bir kuruluș olan TRT kurumu, teftiș ve murakabe bakımından yalnız özel kanunumun hükümlerine tabi olup bunın dışında 1961 Anayasasından 25 yll önce çıkmıș bulunan 2999 sayılı Kanunun 5 inci maddesinin Maliye Teftiş Kuruluna verdiǧi teftiş ve murakabe yetkisine dayanılarak Maliye Bakanlı̆ı tarafından teftișe tabi tutulamaz. Aksi halin kabulü, merkezî idarenin, Anayasay. la öngörülen özerklik ilkesine ve 359 sayılı Kanun hükümlerine ay krrı bir müdahalesi olur". Yukarıda izah olunan sebeplerle özerk bir Anayasa kuruluşu olan TRT Idaresinin teftiş ve murakabesinin yalnızca 359 sayılı özeł Kanunu hükümlerine bağlı olduğuna ve bu hükümler dışında 299 sayılı Kanunun 5 inci maddesine dayanılarak Maliye Bakanlı̆̆ı tarafından teftișe tabi tutulamıyacað̆ına... oybir liğiyle karar verildi» demektedir.

Radyo idarelerinin Özerkliği konusunda Alman Anayasa Mahkemesinin bir kararı bütün dünyada büyük yarkkılar yapmıștır. Alman Radyo Idareieri Anayasa gereğince özerk olmadıkları halde, Fede ral Alman Anayasa Mahkemesi bu kuruluşların özerk olması gerek. fiğini ilgi çekici bir gerekçe ile hükme bağlamıştır (33).

Alman Federal Anayasa Mahkemesinin 28.2.1961 guin ve 23 say1l, bu Kararının burada tetkiki gerekir. Kararın konusu șudur :

(33) Yukanda Not 7'e bakınuz. 
Federal Alman Hükûmeti tün, Almanyaya ait meseleler hakkında yaymlar yapmak üzere 25 Temmuz $1960^{\prime}$ da mahdut mes'uliyetli bir şirket kurmuştur. Bu şirketin kuruluşu ve dolayısıyla federal devletin radyo yayınları yapması muhtelif bakımlardan federal anayasaya aykırı görülmüștür. Alman Federal Cumhuriyetinin 23 Mayıs 1949 tarihli Anayasasının 5 inci maddesine göre kherkesin kanaat lerini sözle, yazı ve resimle yaymak ve engele rastlamaksızın herke sin erişebileceği kaynaklardan istifade etmek hakkı vardır. Basın hürriyeti ve radyofonik ve sinematografik haber alma hïrriyeti temin edilmiştir. Sansür konulamaz». Alman Anayasa mahkemesi nezdinde açılan dâvada federal hükûmet kendi tutumunun Anayasaya aykırı clmadığı görüşünü savunmuştur. Federal Hükûmetin fikrine göre radyo yayınları yapmak, posta ve uzaktan haberleşme işlerine girer. Bunda ise federal devlet yetkilidir. Daha eski Alman devlets zamannda bile telekomïnikasyon ișleri merkezi devlete ait idi. Federal devlet bu bakımdan radyo neșriyatı yapmasının Anayasaya aykırı olmayacağı kanaatindedir.

Anayasa Mahkemesi verdiği kararda telekomünikasyon işlerinin tanziminin federal devlete ait olduğunu, ancak bu tanzimin muayyen frekanslarm tevzii ve radyo verici tekniği ile ilgili husus. larda olabileceğini, programlara müdahale veya bizzat program ıanzimi şeklinde olamıyacağını, çünkü radyonun âmme efkârının leşekkülünde basın yanında en mühim amil olduğunu ortaya koy. muş ve federal Anayasanm 5 inci maddesinin radyo hürriyetinden hahsettiğini, böyle bir hürriyetin teminat altında bulunması için federal devletin veya başka gruplarm radyo yayınjarını tanzime müdahale edemiyeceklerini ortaya koymuştur. Anayasa Mahkemesi bu arada federal devletin merkezî, siyasî kuvvet olduğu, onun halk efkârının teșekkülüne tesir etmemesi gerektiği fikrindedir. Anayasa mahkemesine göre, Anayasanın 5 inci maddesindeki teminatın gerçekleşmesi için özel tedbirler alınmalıdır. Eğer Devlet, statüsü keyfe göre deģişebilen bir şirketin hisselerini elinde tutarak onun vasıtası ile yayın yaparsa, teminat ortadan kalkacaktır. Bu rönde radyo müesseselerinin, teşkilât ve idare itibariyle federal devletten ayrı bağımsız olması gerekir.

Almanyada bu konunun inkişâfı ve varılan neticeleri bahse ko tnu karar etraflı şekilde tahlil etmektedir.

«Reich postası ile bu program şirketleri arasındaki hukukî münasebetler ilk defa 1926 senesinde, vahdet arzeden bir şekilde ve 
e1raflı olarak tanzim edildiler. Bu tanzim de Reich postası kendisi. ne ait verici tesislerin eğlendirici radyo neșriyatı için kullanılması hususunda muayyen şartlara bağlı ruhsatlar verilmesi yoluyla olu. yordu» (34).

«Mezkûr şartlara göre temsillerin evsafı, program, haberler ve konferanslar servisinin şekillendirilmesi bakımından, program şirketleri şartlar meyanına derc edilen özel kaidelere bağl idiler. Politik bakundan yayuları murakabe etmek üzere her bir pnogram sirketi nezdinde bir murakabe komisyonu kurulmuştur. Bu komis. yonun azalarn kısmen Reich, kısmen de yetkili Land Hükûmetleri tarafından tayin ediliyordu. Programın kültüirle ilgili meseleleri için bir istişare beyeti kurulmuștur. Bu heyetin üyeleri Reich İçişleri Bakanının tasdiki ile yetkili Land hükûmetleri tarafından seçiliyor du. Murakabe ve istișare komisyonlarının faaliyet ve yetkileri hak. kında teferruatlı şartlar arasına konmuş olan hüküumler de bulunuyordu».

1932 senesinde radyo teșkilâtı geniş ölçüde değiștirildi ve bir "Devlet Radyosu» yönünde geliştirildi. Bu reform'un prensipleri "radyonun yẹiden tanzimi esasları"nda çıkmaktaydı. 1933 senesinḋe Radyo bir nasyonel sosyalist propaganda aleti haline geldi. Yetkili Vekil halkı aydınlatma ve propaganda vekili idi. Teknik meseleler Reich Postasinda kaliyordu.

«İkinci Dünya Harbinden sonran Alman makamları tarafından radyo tesisleri ișletilmesi evvelâ yasak edildi. Müsadere edilmiş olan vericiler, radyoyu peyderpey tekrar Almanların ellerine geri veren, işgal kuvvetleri tarafundan işletildi. Batıdaki işgal kuvvetle. ri devletin radyoya her türlü tesirini bertaraf etme gayesini güdüyordu». "Bugün Almanyada âmme hukukuna ait dokuz radyo mü. essesesi vardır. Eski Amerikan işgal bölgesindeki rædyolar (Bav. yera, Hes ve Güney Almanya Radyoları, Bremen radyosu) Land kanunlarıyla kurulmuşlardır». "Anayasasının mer'iyete girmesinden sonra radyolarnn kâh federal kanun koyma yoluyla, kâh Landlarnn kendi aralarındaki veya Landlarla federal devlet arasındaki anlaşderal devlet ve Landlar da radyoyu mukavelelerle tanzime gayret malar yoluyla yeniden tnzimi hususunda gayret gösterilmiştir». Feetmişlerdir.

(34) Tamamı 60 sayfa olan karardan konumuzla ilgili parçalar alınmıştır. 
25 Temmuz 1960 tarihinde devlet Başkanı ve devlet Bakanı Schaffer tarafindan temsil olunan Federal Alman Cumhuriyeti, ma. karrı Köln olan mahdut mesuliyetli Alman televizyonu șirketini kurdu. Şirketin vazifesi, bütün Almanyada ve yabancı memleketlerde radyodan istifade edenlere Almanya hakkmna etrafl bir fikir verecek sekilde radyo ve televizyon yaym yapmaktı. Serbest Hansa Sehri Hamburg ve Hessen Land'ı Federal Devletin Anayasa ile kendisine terettüp eden vazifeleri ihlâl ettiği idiası ile durumun Ana. yasa Mahkemesinde karar altına alınmasını talep etmiştir.

Açılan dâvada ileri sürülen iddialara göre, "Federal devlet șirketin kurulmasiyla talep sahiplerinin Anayasanın 5 inci maddesin. den doğan haklarını da ihlâl elmiștir. Anayasanın 5 inci maddesı devlete radyoyu yönetmek veya tesir altında bırakmayı meneder. Şirketin kuruluṣu talep sahiplerinin haklarını, kanunun vericile rin organizasyonu hakkundaki kayd, ihtirazisinin nazarı itibare alımmaması dolayısı ile de ihlâl edilmiștir. Anayasanın 5 inci mad. dcsi radyo hürriyetinin tahditlerinin politik bakımdan bitaraf ve bağımsız bir radyonun teminatını teşkil edecek şekilde kanunen tanzimini emretmektedir. Radyo vericileri âmme hukuku kanunla. ı ina gëre teşkillâtlanmak ve programlarını yaymak için gerekli teknik tesislere sahip olmalidurlar. Bu yüzden Federal Posta üzerinde tasarruf kabul olan radyo frekanslarmı ve radyo tesislerini Landlara tahsis etmelidir.s

"Anayasa hükümleri arasındaki irtibatı göz önünde tutan bir ıefsir tarzına göre, federai devletin filn ve basın için yalnız çerçve hükünler koyma yetkisi varken, radyonun tümü için bir ka. nun koyma yetkisi bulunduğu kabul edilemez». "Büitü bunlara zamimeten radyo bir kültür hadisesidir. Kültür meseleleri maddeten idare ve tanzim edilebildikleri nisbette, Anayasanın temel kai. desi mucibince eger, Anayasa federal devlet lehine hususî istisnalar ve tahditler öngörmenișse, Landlarm yetkisi sahasına girerler. Anayasanın federal devlet yapısı lehine ve kuvvetlerin tesirli bir sekilde taksimi gayesi ile ihtiva ettiği bu temel kaide, kâfi derece. de sarih bir istisnai tanzim tarzı olmaksızın federal devletin yetkiJi bulunduğunu kabule manidir. Halbuki böyle istisnaî bir kaide mevcut değildir.»

«Reich'in ve Landların teșirinin yayımların politik bitaraflığın, yayın șirketlerinin teşkilât bakımından nötrlüğünï ve radyoda serbest fikir beyanı hürriyetini (Weiner Anayasas 1 md. 118) te- 
mine yaradığı mahdut bir șekilde doğrudur. Bu hususta yalnız 1 inci madde hükmii nazarı itibare alınabilir. Bu hükme göre, Radyo hiç bir partinin hizmetinde değildir. Bu yüzden baitün haber ve konferans servisinin sıkı bir şekilde partiler üstünde tanzimi gerekir. Fakat bunun dışında șartnamelerin yardımı ile neredeyse bir sansüre yaklaşacak derecede devletin bir tesir ve murakebesi gerçekleşmiş olmaktaydı».

"Eğer uzaktan haberleşme ile münasebet halinde olan radyo ile ilgili yetki sadece verici tekniğine mïteallik hususlara inhisar edjyorsa, federal posta bu nevi ruhsat ve mukavelelerde münhasiran verici tekniğine müteallik hususları nazarı itibare almaya mec. burdur. Bu sahanın dışına çıan «mükellefiyetler» caiz değildir». Federal devletin bu yetkileri kendisine sadece programın bazı kl. sımlarım (bilhassa siyasî partilere yayın zamanları tahsisi ve mu. ayyen haberlerin verilmesi) yahut radyonun muayyen hukukî prob. lemlerini (uneselâ telif hakkı) tanzin yetkisi verir. Federal devlelin sair yetkileri, onun meselá millî müdafaa ile, gümrük ișleri ile, federal cürüm mercii ile ilgili görevlerinin mahiyetinden çıkarıla bilir. Mamafih federal devletin bütün bu yetkileri, bir arada da na. zan itibare alınsa, radyo yaymlarmin tanzimi hususunda kanun koyma yetkisini meydana getirmezler.

«Federal devletin, federal hükûmetin fikri hilâfına işin mahi. yetinden ötürü, içeri doğıu yani, Federal Alman Cumhuriyeti hal. kına karşı bölgeler üstü millî temsil vazifesine yarayan radyo ya. yımlarını kanunla tanzim etme yetkisi yoktur. Bu hususta ilgili ida. iî yetkiler de federal devlette bulummaktadırlar. Bu yüzden Anayasanın 87. maddesi 3 üncü frkrasına dayanarak bu gaye için kanun yoluyla bir f̊deral makam veya âmme hukuku müessesesi de kura. maz". "Posta ve uzaktan haberleşme işlerinin tanzimi yetkisi Anayayasanın 5. maddesinde radyo yayınları ve yayım yapanlar hakkında maddî hiukık ve teşkilât bakımından aranan veya caiz görülen pren. sipleri kanunen tanzim yetkisini de kapsamaz». Bundan çlkan ne. tice, Federal devletin uzaktan haberleşme tesisleri kanunu, § 2'ye göre vereceği ruhsatları ve postaya ait radyo tesislerini kullanma hususunda yapacağı mukaveleleri, verici tekniğinin dişına çıkan nïikellefiyetlere băglı kılamıacağıdır.

«İçeri doğru millî̀ temsil zaruretinden yeni Federal Alman Cum. huriyeti halkı önünde milletin kendi kendisini temsil etmesi «de. vamlılı̆̆ı muhafaza eden an'antyi koruma" gereğinden de federal devletin radyo yayımları yapma hususunda tabî̀ bir yetkisi olduğu 
çkarılamaz. Bu gibi hususları devletin teşvik etmesi şüphesiz za. ruridir. Fakat bu gibi vazifelerin multevasının yakınen tayin ve tav. sif edilemiyecekleri de gözden ką̧ınayan bir husustur. İ̧̧eri doğru milleti temsile yarayan bir çok kültür tezahürleri vardır. Nihayet bütün terbiye ve eğitim "milletin devamllhğını koruyan an'ane» olarak' anlaşılabilirir".

"Anayasanın 5. ci maddesi, vatandașın devlete karşı, içinde likrini serbestçe beyan edebileceği bir hürriyet sahasına riayeti talep hususunda, ferdî temel hakkındain daha fazlasını ihtiva etmek. tedir. Anayasarın 5 inci maddesinin 2 nci fikrasının 2 nci cümlesi dolayısıyla, özellikle basının, haberin ve kanaatin elde edilmesinden yayılmasına kadar ki müessesevî bağımsızlığı garanti altına ahınmaktadır. Basııı veya onun bir kısmmı doğrudan doğruya ve ya dolayisıyla devlet eliyle tanzim etmek veya gütmek bu Anayasa garantisine aykırı olur, devletten bağımsız gazete ve mecmuaların sayılarının çokluğu dolayısı ile, devletin tesirinin serbest basın görünüşünde muhteva itibariyle hiç bir değişiklik yapmadığı haljerde devlet tesiri, bu Anayasa garantisi ile ancak bağdaşabilir». "Anayasanın 5 inci maddesinin radyo bakumindan önemi, bu maddenin izah edilen muhtevası nazara alınmadan değerlendirilemez. †ेlerde söz konusu edilecek bir hususiyeti mahfuz kalmak üzere, radyo ve basın gibi, âmme efkârına tesir icra edilen ve vasıtasıy. ja âmme efkârının teşekkül ettiği kütle haberleşme vasıtalarındanđłır. Radyo âmme efkârı teșekkülüniün sadece vasıtası olmaktan fazla bir şeydir. $O$ âmme efkârnan teşekkülünün önemli bir amilidir. Âmme efkârının teşekkülïndeki bu tesir sadece haber yayımları, siyasî yorumlar, halihazır geçmiș veya gelecekteki siyasî meseleler hakkında yayın serilerine inhisar etmez (35). Fikir teşekküü aynı șekilde temsillerle, müzik yaymlarıyla, kabare programlarının nakli ile, bir temsilin sahneye konușu ile de olur. Hem radyo prcgrammm, bilhassa neyin yayınlanmaması gerektiği, neyin dinleyicileri ilgilendirmiyeceği, neyin âmme efkârı için zarar sözkonusu olmaksızın ihmal edilebileceği, yayınlanacak seyin nasıl söylenip, nasıl şekillendirileceğinin karara bağlanması bakımından muayyen bir temayülü vardır. Böyle bir müşahade içinde, basının vannda bulunar, en az onun kadar ehemmiyeti haiz kendisinden vazgeçilemiyecek bir kütle haberleșme vasıtası olan radyo için de

(35) Teknik tesisatın kullanılması ve kütlelere hitap etme konusunda Lademann, Jahrbuch für Internationales Recht. 8. 1957/1958 s. 307 v.d. bakmiz. 
bu müessesevî hürriyetin en az basın kadar önem taşıdığı açıkca görülür. Anayasanın 5 inci maddesinin 1 inci frkrasının 2 nci cümle. sinde basın hürriyetinin yanında radyo ile haber yayılması ve film hürriyetinin garanti altına alınmış olınası bu hususu sarahaten ifade etmektedir".

«Bu söylenenlerle, umurniyetle radyo hürriyetinin ve hususiyle radyoda haber yaylması hürriyetinin Anayasanın 5 inci maddesine göre kifayetli bir șekílde terninat altına alınmasının yolu hakkında henüz bir fikir beyan edilmiş olmamaktadır. Bu hususta radyonun basından ayrıld $\breve{g ̆}_{1}$ hususiyeti ehemmiyet iktisap eder. Gazete idarehanelerinin, gazete matbaalarının ve gazetelerin istenilen sayıda kujulabileceği ve yürüitülebileceği doğru değildir. Basın ile radyo arasındaki fark, Alman basınında müstakil ve temayülleri, politik renkleri, yahut dünya görüșleri itibariyle birbirinden deǧişik çok sayıda basın mahsulünün mevcut olması, halbuki radyo sahasında, gerek teknik sebeplerden, gerek radyo yayınlari yapmanın çok biiyük millî masraflan icap ettirmesi yüzünden böyle yayın yapan müesseselerin sayılarmın nisbeten kiiçik kalmaya mecbur olmasıdır. Radyo sahasındakì bu hususî durum. Anayasanın 5 inci maddesinde teminat altına alınan radyo hürriyetinin gerçekleşmesi ve idamesi için özel tedbirler alınmasını gerektirir. Bu gayeye yarayan vasitalardan birisi bugün mevcut radyo müesseselerinin kuruluşunda cari olan prensiptir. Radyo yayınlar tesirinin dışında kalan yahut olsa olșa ancak devletin mahsus bir murakabesine tabi tutulan bir âmme hukukî hükmî șahsı yaratılır. Bu hükmî şahsın organlar, fiilen ve münasip nisbetler dahilinde bütün önemli politik içtimaî ve kendisine mahsus dünya görüșle1'ine sahip grupların mümessillerinden terekküp etmektedir. Bunların, program yapma ile inesgul ve programa tesir edebilecek șa. hisları, kanunun 5 inci maddesindeki, radyoyla ilgililerin radyoya iștirak ettirilmelerini temin hususundaki prensip yerine getirilecek şekilde kontrol etme ve tashih etme yetkileri vardır. Böyle teminat. larla teçhiz edilmiș bir müesseseye bugünki teknik imkânlar içinde ve Land sathında radyo yaymları yapması hususunda bir inhisar hakkı verilmesi Anayasanın 5 inci maddesi ile çelişmeye düșmemek. tedir. Fakat Anayasann 5 inci maddesinden böyle bir inhisarın bir Land müessesesi lehine yaratılması zarureti asla çımamaktadır». "Mamafik Anayasanın 5 inci maddesi radyo sahasındaki hürriyetin temini bakımından Land Radyo Kanunlarının buldugu ve Federal hukukun radyo müesseselerinde de tatbik edilen şekli emretmemektedir. Bilhassa Anayasa, radyo yayınları yapan müesseselerin 
münhasıran âmme hukuku hükmî şahısları olabileceğini emretme. mektedir. Hak ehliyetine sahip olan bir hususî hukuk șirketi de eğer teșkilâtı, kendi içinde âmme hukuku muiesseselerinde oldu. ğu gibi cemiyetin bütün önemli kuvvetlerinin söz sahibi olmasına ve haber alma hürriyetinin masuniyetine kâfi derecede teminat teşkil ediyorsa, bu neviden yayınları yapabilir. Eğger meselâ kanun voluyla radyonun spesifik gayelerini, bilhassa onun müessesevî hür. riyetini teminat altma alabilecek özel bir şirket şekli yaratılırsa ve bu şartları taşıyan radyo yayınları şirket, banka ve sigortaların murakabesinde olduğa gibi bir devlet murakabesine tâbi olursa, böyle bir şirket bakımından Anayasaya uygunluk hususunda endișe edilemez».

"Her halde Anayasanı 5 inci maddesi bu modern âmme efkârı âletinin ne devlete, ne de cemiyetin bir grubunun eline verịlmesiri istememektedir. Radyo yaymları yapanların, organları üze. rinde bütün söz konusu olan kuvvetler tesir sahibi olacak ve bütün program içinde söz söyleyebilecek șekilde teșkilâtlanmaları ve bü. tün programm muhtevasında asgarî bir muvazene, objektiflik, kar\$llıklı saygıyı teminat altına alan bağlayıcı prensipler bulunması gerekınektedir. $\mathrm{Bu}$ da ancak teșkilàta ve işin mahiyetine taallûk eden bu prensiplerin kanun yoluyla bağlayıcı hale getirilmesi il olur. Bu yüzden Anayasanın 5 inci maddesi böyle kanunların korın masını emretmektedir». (36)

«Radyo yayınlarını yapanların zarurî olarak verici tekniğine müteallik tesisler üzerinde malik yahut tasarruf hakkın haiz of maları, veya bu tesisleri ișletmek hakkına sahip olmaları gerektiği Anayasanın 5 inci maddesinden çıarılamaz. Anayasanın 5 inci mad. desi, devlet mümessillerine de Radyonun nötrleștirilmiș hâmilinin organları içinde münasip bir hisse ayrılmasına mani değildir. Ona mukabil 5 inci madde devletin radyo yaynları yapan bir șirketi, doğrudan dogruya veya dolayısıyla hâkimiyet altına alması imkâ. nunı vermez».

"Alman televizyon mahdut mes'uliyetli șirketinin kuruluşu ve mevcudiyeti bu sebeplerle Anayasanm 5 inci maddesine aykırı. dirn.

Bu kadar yalnı Álmanya'ya değil, bütün Batı memleketlerine yol gösterioi niteliktedir. Ve özerklik konusunda Anayasasında açı

(36) Not. 7 dekì karar sayfa 259 v.d. 
hüküm bulunan Türk Radyoları için en geniş yorum addolunabilìr. Bu arada, Türk Anayasasırin bu konuda bütün Batı Anayasalarn. dan önemli surette ileri oldığ̆u da söylenebilir.

F. 359 sayılı kanun hükümlerini İktisadî Devlet Teşekküulleri mevzuatı ile kıyaslayarak konuyu bu açıdan da incelemek faideli olacaktır. Bu arada Kurumun denetimi konusu üzerinde de yeniden durulacaktır.

359 sayıl Kanunum Anayasanın 121 inci maddesi karşısındaki durumu incelenirken $\mathbf{4 4 0}$ sayl Kanunun ne dereceye kadar TRT bünyesi jle kabili telif olduğu sorusu da crtaya çımaktadır. Her ne kadar 440 saylı Kanun 359 sayll Kanundan sonra kabul edilmişse de, bu Kanun iktisadî kamu teşebbüislerini tanzim eder. Bu Kanunun TRT ile ilgisi açıtır. Acaba 440 sayılı Kanun hangi hudutlar içinde TRT'ye kabili tatbikitir? Bu Kanun - atıfları - hangi bakımdan TRT'nin bïnyesi içinde yürütülebilir. Başka bir deyimle 440 sayılı Kanuna yapılan atıflar özerklik ile kabili telif midir? 440 sayıl Kanun yalnız ekonomik özerklikten bahseden bir Kanundur. TRT Kurumunun özerklik prensibi ise çok daha geniştir. Diğer taraftan 440 saylh Kanun ekonomik özerklikten bahsettiği halde hakikatte bu sahada kamu iktisadî teșebbüislerine hemen hemen hiç özerklik vermemiştir. (37)

Tetkiki gereken bașka bir problem de 359 ve 440 saylı Ka. nunların bir arada tatbiki ve bu bir arada tatbikin özerkliğe aykl. rı neticeler meydana getirip getirmediği noktasıdır. Her birinin - kendine göre - muhtariyet anlayışı olan bu kanunlar bir araya ge. lince Anayasanın TRT muhtariyeti tatbik edilmez hale gelmekte. dir. Kanurla özerkliğin verilmiş olduğunu beyan etmek yetişmez: Değişik kanunların - iç içe geçen ve bir arada ișleyen dişli çarklar gibi - bir arada vazife görmelerinde, bütün ișleyiște özerkliğe aykı$r_{1}$ bir unsurun bulunmamas 1 gerekir. 359 ve 440 saylı Kanunlar bu sahada iyi bir misâl olabilir : jki kanun bir araya gelip birbirleri ile hemahenk işletilmek istendiğinde, Anayasanın 121 inci maddesindeki özerklik tatbik edilemez hale gelmektedir. Danıştayın bu konuya dokunan kararları bu sahada Anayasanın Özerklik mefhu-

(37) Konu ile bilhassa 440 sayll Kanunun programlar, bütçeler, kısa ve uzun vadeli programlarla ilgili 13 üncii ve 17 nci maddelerine ve iktisadî Devlet Teşekkülleriyle Müiesseseleri ve iștirakleri hakkındaki tüzügün $21,49,76,77,82,83$ ve 84 ncï maddelerine bakını. 
munun 359 ve 440 sayılı Kanumlar tarafından ihlâl edildiğini zaten göstermiştir.

359 sayılı Türkiye Radyo-Televizyon Kurumu Kanununun 33. maddesine göre, özel hükümler sakh kalmak kaydiyle kurum hakkında Iktisadî Devlet Teşekküllerine uygulanan genel hükümlerin uygulanacağı ve bu hükümlerin uygulanmasında da keza igili Bakanlığın Turizm ve Tanıtma Bakanlığı olduğu, belirtilmiştir. Bı hükmiü şumulïi ve mânașı nedir?

TRT Iktisadî Devlet Teșekküllerinden tamamen farklıdır. TRT Kurumuna farklı statünün tamıması, bu kurumun sahip olması gereken "larafsızlık» niteliginin bir neticesidir. (38)

Iktisadî Devlet Teşekküllerini düzenleyen 440 sayılı Kanunla. TRT Kurumu hakkındaki 359 sayll Kanunun farklı bir espriyle dü. zenlenmiş olması, 440 sayılı Kanun hükï̈mlerinin TRT Kurumuna tatbikini imkânsız kılmaktadır. Bu farkhılık, söz konusu kanunla. rın dikkatli tetkiki neticesinde kendilig̈inden ortaya çımaktadır. Șöyle ki :

- 440 saylı Kanumun 2. maddesinde «bu kanunun amacı Iktisadî Devlet Teşekkülleri ile Müesseseleri ve iştiraklerin ulusal eko. nomimize faydalı olabilmesi için özerk bir tarzda, karma ekonomi. nin kurallarma ve ekonomik gereklere uygun olarak yönetilmeleri. ni, kârlılık ve verimlilik anlayışı içinde çalışmak ve sermaye biriki. mine yardım etmek suretiyle daha fazla yatırım kaynağı yaratmala. runı ve bu amaca ulaşmak için denetlemelerini sağlamaktır» den mektedir. Şu halde bu kanundaki özerkliğin amacı tamamen «eko nomik»tir; ekonomik esasa yönelmiş özerklik, binnetice merkez idare ile olan münasebetleri; "tarafsızlık» amacına yönelmiş özerk liğin neticelerinden tamamen ayrı olduğu için, birinciler konusunda ihdas edilen mekanizmanın, ikinciler (yani TRT Kurumu, Univer siteler gibi) konusunda da kiyasen tatbikine imkân yoktur.

- 440 sayll Kanunun 2. maddesirin (B) bendinde "Iktisadi Devlet Teşekkülleriyle müesseselerin kuruluş, yönetim ve denetimi ve iştiraklerin yapılması ve yönetimi bu kanunla düzenlenir ve yü. rütülür» denmiștir. Aynı zamanda 1. maddede de "İktisadì Devleı Teşebbüsleri... kuruluş kanunlannda bu kanuna tabi olacaklan be lirtilen teșebibüslerdir» demektedir. Nitekim PTT Genel Müidürlügui,

(38) Devletin programlara tesir etmemesi bahsinde Bredow Vier Jahre deut. scher Rundfunk 1927, s. 20 v.d. bakmız. 
Sümerbank, Türkiye Kömür İşletmeleri v.s. gibi devlet teşebóüislerinin kuruluş kanunlarunda, bu teşebbüislerin 3460 (halen 440) savlı kanuna tabi oldukları açıkca belirtilmektedir. Kuruluş kanınlarına göre bu müiesseselerin hepsi, faaliyetlerinde, gerek bağh bulunduklarn Bakanlı̆̆, gerekse Bakanlar Kurulunun idarî vesayeti altındadır; çalışma programlarının tatbiki, ilgili Bakanlıkların tasdiki ile tekemmül etmektedir. 440 sayıl Kanunun verdiği eamaç ve konu” gözönünde tutulursa, bu teşekküllerde kurulmak istenen ida$r \hat{i}$ vesayetin mevcudiyeti normaldir ve ana gaye ile çelişme halinde değildir.

Buna mukabil TR'T Kurumu konusunda tutulan yol farklıdir. Bir kere kurum tamamen farklı bir gaye güttǚ̆̈i, farkl ${ }_{1}$ bir zemin üzerine oturtulduğu için, 440 sayılı Kanunun yukarıda sözii edilen 2. maddesinin (B) bendi hükmü TRT Kanununda yer almamıṣır Ustelik TRT Kanununda genel esasları muhtevi bulunan 1. bölitim bu kurumun, diłger İktisadî Devlet Teşekkïüleri Kanunlarında gö. rüldüĭgi gibi, 3460 (halen 440 ) sayılı Kanuna tâbi olacağına dair bì hükmï ihtiva etmemektedir (her ne kadar 359 sayll kanunun 33 maddesinde, Kurum hakkında, kanuni istisnalar saklı kalmak üze re tktisadî Devlet Teşekkülleri hakkındaki Kanun hükümleri tatbik edileceği söylenmiş ise de, bu hükmün tamamen ayrı bir anlam ta. \$̦ılı̆ı biraz sonra izah edilecektir). Bilákis 359 sayılı Kanun, istis. naen, İktisadî Devlet Teșekküileri hakkındaki kanuna atıflarda bu. lunmak suretiyle ( 33 ve 47 , maddelerde olduğu gibi), TRT Kuru. munun kaideten 440 saylı Kanunun genel çerçevesi dışında kaldı: ğını açıkca göstermiştir. Eğer TRT kurumu, genel yönetim ve dene tımi itibariyle 440 sayh Kanunun genel hükümlerine tabi tutul. muş olsayd, istisna teșkil eden bu atıf ve sarahatlara şüphesiz lü zum kaliniyacaktı.

Bu gerçek, 359 sayılı Kanunun gerekçesinde ve Yasama Mec. lislerindeki miizakerelerinde açıkca ifade edilmiştir. Kanunun ge. rekçesinde aynen şu ifade yer almaktadır: «Kurum, gayesi âmme hizmeti olan... bir İktisadî Kamu Kurumudur. Bu sebeple Kuru mun tktisadî Kamu Kuruluşu niteliği, onun ticarî maksatla ve kâr temini gayesiyle hareket edecek ticarî bir radyo televizyon kuru. luşu olduğu anlammı taşımaz.» Gerçi Komisyon raporunda da, bu konuda șöyle denmektedir: «...gerçekten kurumun bir iktisadî kamu teşebbüisü olduğunu tasrih etmek, ancak bir Iktisadî Dovle! Teşekküilï olmadığmn da belirtmek gerekmektedir. Gerçekten, kı̈s rumun tasarı gerekçesinde de belirtildiği veçhile, behemahal ve. 
riṃililik ve kâr sağlama amaçları ile çalıșması mümkün olamıya. cağı gibi, organlarnnın kuruluş tarzı itibariyle de İktisadî Devlet Teșekküllerine uygulanacak genel esaslara uyması imkânsızdır. Bu itibarla, kurum bu maddede (1. maddede), bir kamu iktisadî teşeb. büsü olarak gösterilmiş, ancak, bir iktisadî devlet teșekkülü olduğu beyar edilmemiştir. İktisadì Devlet Teşekküllerine uygulanacak isasların bu kanunda tatbik edilmesine ait istisnalar ancak ilişkin bulundukları konulara münhasırdır. Keza tasarmmn Cumhuriyet Senâtosundaki müzakereleri strasında geçici komisyon sözcüsii şu beyar:da bulunmuştur: (Kurum) diğer Iktisadî Devlet Teşekkülleri gibi değildir, kendisi zaten İktisadî Devlet Teșekkülü değildir» (39).

Bu açıklamalar 359 sayılı Kanunun, «Bu Kanundaki özel hükümler saklı kalmak kaydiyle, Kurum hakkında İktisadî Devlet Tesekküllerine uygulanan genel hükümer uygulanır» diyen 33; ve Kurum Yüksek Denetleme Kurulunun denetimine tabidir" diyen 34. maddelerine gerçek anlamını vermekle, bu maddelerin tatbik alanımı sarahatle çizmektedir. Şöyleki, Iktisadî Devlet Teșekkülleri hakkında olup TRT kurumuna da uygulanacak genel hükümler, 33 ve 34. maddelerin içinde yer aldığı bölüme ilişkin «mali hükümlerdir» ve bunlar da «sermaye, yatırım progranu, bütçe ve hesaplar»a taal. lûk etmektedir. Bu hükümleri atıf yoluyla TRT'ye tatbik sebebi, bu konularda TRT ile klâsik İktisadî Devlet Teșekkülleri arasmda șekil bakımından bir fark bulunmamasıdır. Hatta TRT Kanunu bu malî konularda dahi daha da ileri giderek, kurumun kuracağı ortaklık. ları Yüksek Denetim Kurulunun denetiminden uzak tutmuștur (Bk. mad. 30).

Bu husus, aynca Hükûmet tasarısında, bugünkü 33. maddenin kaynağını teşkil eden 55. maddede açıkca belirtilmiş bulunuyordu. Bu madde, ubu kanundaki özel hükü̈mler sakh bulunmak kaydiyle TRT'nin bütçe ve hesaplaryyla denetiminde Iktisadî Devlet Teșek. küllerine uygulanan hükümler tatbik olunur» denmekteydi. Hük û. met tasarısının «çeşitli hükümler» kısmında bulunan mezkùr 55. madde Kanun sistematiği mülâhazasiyle, oradan alınıp, geçici Ko. ırisyon tasarısının "Mali Hükümler» bölümüne yerleștirilmiş, $\mathbf{k}_{\mathbf{i}}$. sım başlığına binaen tekrara düşmüs olmamak için, bu maddenin «...bütçe ve hesaplarıyla denetiminde.... ibaresi çıkarlmıştır. 440 sayılı Kanuna, bağı teșekküllerin özerkliğı sahaları da ayrıdır. Kal

(39) Cumhuriyet Senatosu Tutanak Derg. Dö. 1. Cilt 5, Top. 2, 123. birleşim Sayfa 452. 
dı ki bilindiği üzere İktisadî Devlet Teşekkülleri yalnız işletme faa. liyetlerinde özerktirler. Yönetim Kurulu ile Genel Müddür ve Genel Müdür Yardımcılarının tayin ve değiştirilmesi 440 sayılı Kanun ge reģince ilgili Bakanlk yerine Bakanlar Kurulunca yapılmaktadır 359 sayll 1 Kanunla kurulan TRT için, Kanun vazın kabul ettiggi özerklik İkłisadî Devlet Teşekküllerine nazaran çok geniş bir anlam taşımaktadır. Meselâ İktisadî Devlet Teșekküllerinde Yönetim Kulrulu üyeleri ile Genel Müdür ve Genel Müdür Yardimclları Bakaniar Kurulu kararı ile tayin edildiği ve bu suretle bir bakıma özerklik sağlama amacı güdüldüŭü halde, TRT için bu da kâfi görülmiyerek sözii geçen görevlere tayinlerde Bakanlar Kurulunun yetkisi daraltılmış ve Yönetim Kurulunda çoğunluk Hükî̀met dışından secilenlere verilmiștir. Ayrica gerek Meclis ve gerekse Senatoda tasarının müzakeresinde özerklik konusunda çok hassas hareket edilmiș ve kurumun iștirak yapması hususunda, 440 sayılı kanundakı sistem, yani Bakanlar Kurulu kararı, uygun görülmemiş ve bu yetki TRT'nin Yönetim Kuruluna verilmiștir. Bu itibarla kanun va żını TRT'nin özerkliği hakkında anlayıșı ile İktisadî Devlet Te șekküllerinin özerklik anlayıșının aynı anlamda mütalâası gerekmiyeceği kanaatındayız.

TRT'nin bir kamu teşebbüsü olması itibariyle tasarınn Hü kûmetçe hazırlanması sırasında yatırım, finansman ve bütçeler ko nusunda Iktisadî Devlet Teşekkülleri statüsüne tabi olması Mali. ye Bakanlığınca talep edilmis ve tasarı bu yolda hazırlanmıs bu. lunmakta idi. Ancak Meclis Komisyonlarında - Yatırım ve Finans: man Programlarıyla Iş̧letme Bütçesi hakkında I. D. Teșekküllerine uygulanan genel hükümler uygulanır - hïkmü tasarmın bölüm başlığında esasen mevcut olduğu mülâhazasiyle maddeden. Yatt. Jım ve Finansman Programlarılyla işletme bütçesi - ibaresi çıkarıl. mıș bulunmaktadır. Bu bakımdan 359 sayllı Kanunun 33. maddesi. nin bu anlamda mütelàasının, Kanun vazının maksadına uygun olacağı düşünülmektedir. Keza 359 sayılı Kanunun 34. maddesi bizzat ilgili Bakana TRT hakkında inceleme yetkisini vermemiștir. Bu jtibarla 440 sayll Kanunun 9. maddesinin TRT'ye tatbik edilmesi. nin Kanun vazın özerklił̆i anlayıșı ile kabili telif değildir. Yukarı. da izah edildiği gibi $\mathbf{4 4 0}$ sayll Kanunun ana hükümleri dișında ka. lan TRT'nin iktisadî kuruluşu nasıldır? TRT Kurumu Iktisadî Ka. mu Tüzel Kişiliğine sahip bir özerk kuruluştur. Kurum bu kuruluş dolayısıyla 440 sayılı Kanun gereğince iktisadî faaliyetlerinde özel hukuk hükümlerine tabidir. Kurumun gelir kaynakları 359 sayıl, Kanunun 26. maddesinde tesbit edilmiştir. 
359 sayll Kanunun 1. maddesinde Türkiye Radyo-Televizyon Kurumu, bir "KAMU İKTİSADÎ TEŞEBBÜSƯ olarak tarif edil. miştir (40). TRT'nin İktisadî Devlet Teșekkülü karekteri, veya digèr bir deyimle, İktisadî Devlet Teşekkülleri nizamına istisnaî ola rak tabiiyeti, 359 sayılı Kanunun «Mali Hükü̈mler» başlı̆̆ını taşı yar üçüncü kısmında yer alan hükümler muvacehesinde tesbit olu nabilir. Adı geçen kısımda yer almamıs bulunan hususlar gene! hükümlerle tamamlanabilir. Bu 359 sayllı Kanunun, 33. maddesi. nin bir geregidir.

359. sayılı Kanumun, ilgili hükümlerinin tetkiki, TRT'nin eko nomik yapısını açıklıkla ortaya koymaktadır: 359 sayl Kanunun 24-28. maddelerinde TRT Kurumunun malî konularda Iktisadî Dev. let Teşekküllleri metodlar ile çalışabileceği teyid olunmuştur. Bun dan başka iktisadîlik vasfının bir sonucu olarak ortaklıklar kura bileceği öngörülmiüş (Mad. 30), ücretli hizmet prensibinin icab) olan tarifelerin tesbiti ile yetkili kklınmıș (Mad. 31), kredi temini hakkı tanınmıs ve (Mad, 32), personeli 440 sayılı İktisadî Devleı Teşekküllerine uygulanan Kanun hükümlerine tabi tutulmuştuı (Mad. 47/2). Ayrıca 359 sayılı Kanunun gerekçesinde ve müzakere zabıtlarında kurumum iktisadî karekteri ve bu karekterin icabı ifa edeceği fonksiyonlar üzerinde sarih açılamalar mevcuttur. Yukarı. da da açıklandığı gibi, TRT Kurumu İktisadî Karmu Tüzel Kişiliğine sahip bir özerk kuruluştur. Kurum bu kurulus dolayısıyla 440 sayılı Kanun gereğince iktisadî faaliyetlerinde özel hukuk hüküimlerine tabidir. Kurumun gelir kaynakları 359 sayıl Kanunun 26. maddesinde tesbit edilmiştir.

Bir iktisadî kamu teşebbüsü olmasına rağmen Kurumun, yüklendiği hizmetler yönünden, esas itibariyle kâr temin edebilecek bir teşkilât olamıyacağı Kanunda öngörülmiiștür. Filhakika sadece ruhsat resimleri ve reklâm, ilân gelirlerinin sahibi olan ve esas itiba. riyle kâr kastiyle çalışmayan bir müessesenin yüklendiği bu hizmetlerin mïnhasıran bu gelirle karşılanmasına imkân yoktur. Sırf ticarî maksatla çalıșan inüesseșeler hariç, dünyada mevcut diğer bütün radyo ve Televizyon müesseselerinde de durum aynıdır. Me.

(40) TRT șüphesiz bir kamu hizmetidir. Bunun jçin bakınız. Krause, Dié Zuständigkeit zur Ordnung des Rundfunkwesens in der Bundesrepublik Deutschland. 1960, s. 106 v.d.; Krüger, Der Rundfunk im Verfassungsgefüge und in der Verwaltungs ordnung von Bund und Ländern 1960 s. 16 ve 78; Quaritsch, Jahrbuch für Internationales Recht 8 (1957-1958) s. 339 v.d. 
selâ BBC geniş bir gelire sahip olduğu halde, devlet bütçesinden yardım almaktadır. Bu gerçekleri nazara alan Kanun vazı 359 sayılı Kanunun 27. maddesinde kuruñun bütçe açı̆̆ının, devlet büt. çesinden karşılanacă̆ını kabul etmiştir. TRT bir yandan iktisadi teșekküller gibi ücretli hizmet nizamına tabi tutulmus diğer yön. den ifa ettiği kamu hizmeti dikkate alınarak devlet tarafindan yar. dım edilmesi esası kabul edilmiștir, Bilhassa dış yayınlar, kültür ve eğitim yayın ücretlerinin genel bütçeden karşılanması öngörül. müsștür.

Kurum, esas itibariyle müstakil gelir kaynaklarına sahiptir Başlica gelir kaynakları Radyo ve Televizyon ruhsatnameleriyle il. gili gelir ve cezalarla, ilân ve reklâm gelirleridir. Ayrica, konser, temsil ve benzer proggramlara giriș ïcreti, kitap ve plâk ile temin edilecek mahdut gelir kaynakları mevcuttur. Bu gelirlerle, kurum işletme ve ortaklıklar kurảuğu takdirde, bunların gelirleri ve $\mathrm{Ku}$. ruma yapılacak bağıșlar da eklenmektedir. Kurumun hizmetleri arasında yer alan Radyo ve Televizyonda yapılacak okul, halk eğjtimi ve yurt dıșı yayınların gerektirdiği her türlü tesis ve işletme giderleri karşılığının, Kuruma Devlet bütçesinden ödenmesi öngö. zülmüiștür.

Kurum Radyo ve Televizyon ruhsatiyle tarifelerini ve hizmetleri ile igili diğer tarifeleri re'sen düzenleyebilmektedir. Sadece Radvo ve Televizyon ruhsatları karşılı̆̆ ücretler tarifesinin Bakanlar Kurulu kararı ile yürürlïg girmesi kabul edilmiștir (Mad. 31).

Kurum bir iktisadî kuruluş olarak, amaçlarına uygun olmak kaydiyle ve Bakanlar Kurulu Kararnamesi ile gösterilecek esaslar içerisinde ortaklıklar kurma hakkırıa sahiptir. Bu ortaklıklar İktisadî Devlet Teşekkülï sayllamaz ve tamamen özel hukuk hükümle. rine göre yürüitülïr. Kuruma Devlet Yatırım Bankası kredilerinden faydalanma yetkisi tanınmıştır. Görüldiugü gibi TRT Kurumu ikti. sadî bünyesinde de özerkitği belirtici bir sistem içindedir.

G) 359 sayll Kanun Anayasanın 121 inci maddesi ile bağdaş. makta midır?

Hükûmet tasarısımm gerekçeșinde belirtildĭğ üzere 359 sayıl Kanun, Anayasadan dợan "fílî̀ ve hukukî zorunluklara" dayanılarak hazırlanmıș ve 1 inci maddede Anayasa ile öngörülen «özerklik» ifade edilmiştir. İç yaymların esąslarının tesbitinde tek yetkili, Yönetim Kurulu tanınmış ve Hükûmete hiç bir yetki verilmemiştir (Mad. 5). Gerek teşri organın, gerekse yürütme organının hizmetle. 
ri ile ilgili yayınlar konusu da Kanunla tanzim edilmiş ve bunlar di. șinda söz konusu organlara yayın için talepte bulunmak hakkı dahi kabul edilmemiştir (Mad. 11, 12, 13, 14, 15, 16). Sadece millì güvenlikle ilgili haber ve dış yayın konularında ana prensipten kısmen inhiraf edilmiştir (Mad. 17, 18). Yaymlarla ilgili cevap ve düzeltme konuları da özerkliğin gereğine göre tanzim edilmiștir (Mad. 12, 19). Bu suretle yayın konusunda Kurumun özerkliği sağlanmıștır

$B \mathfrak{u}$ gerekçeler daha bidayette Hükûmet tasarısıyla da öngörüll. müş̧ür. Tasarının gerekçesinde şunlar okunmaktadır :

«Kurumun özerkliği Anayasanın 121. maddesi uyarınca tasarı. nın 1. maddesinde belirtilmiş ve bunun gerçeklşetirilmesi için lü. zumlu esasların tesbitine çalışılmış̧ır. Yaynlar tarafsızlığı ile Ka. nun hükümlerine riayet olunması mihaniki bir sistem kurarak sağ. lanmak suretiyle özerkliğin temini yolúna gidilmiştir». Demek oluvor ki yayın konusunda TRT üzerinde herhangi bir yetki veya de netim düşünülmüş değildir ve TRT üzerinde yürütme organına bir hiyerarşik yetki tanımak imkânı yoktur.

Kanunun diğer kısımlarında ve bilhassa hizmetlerin diuzenlen. mesi ile ilgili yönetmelikler ve bütçe konusunda Turizm ve Tanıtma Bakanına tanınmıș bir onay yetkisi görünmektedir (Mad. 28, 47). Ancak bu onay yetkisi Kurumun Anayasaya müstenit özerkliği ile ne derece kabili telif olursa olsun hukukî mahiyeti itibariyle yapıcı veya yok edici karekteri haiz olmayan hafif bir idarî vesayet tezahüründen ibarettir. Filhakika Kuium Yönetmeliklerinin ve büitçesi. nin onayı sadece Kurumun, hizmetinin tanzimi ile ilgili, bazı tasarruflarını tekemmül ettirici bir hududu aşabilecek nitelikte değildir. Nihayet 359 sayılı Kanunun 33 ve 34. maddeleri thükümleri ise aynı hudutları aşabilecek mahiyette değildir. Her iki madde de Kanunun sermaye, yatırım programı, bütçe ve hesaplar bölüimünde yer almiștır.

359 sayll 1 Türkiye Radyo-Televizyon Kurumu Kanununun 34. maddesinde; Kurumun Yüksek Denetleme Kurulu'nun denetimine tabi olduğu. Turizm ve Tanıtma Bakanının, Kurumla ilgili olarak, belli bir hususun incelenmesini Yiiksek Denetleme Kurulundan isteyebileceği yazılıdır. Bu hükümlerden kesinlikle anlaşılacağı gibi, Yüksek Denetleme Kurulu 3460 sayıl Kanunun 10. maddesinde açıklanan şekilde Türkiye Radyo-Televizyon Kurumunda inceleme. lerde bulunabilecek, yani "Kurumun idare şekli ve tarzın ve gayesine ve iktisadî, ticarî ve sınầ esas ve icaplara uygun ve verimli 
ve rasyonel bir şekilde işleyip işlemediğini ve hususiyle mevcut şartlara göre emsali müesseselerle mukayeseli maliyet hesaplarını her hesap yıl içinde en az bir defa tetkik, tahlil ve murakabe ede. cektir». 3460 sayılı Kanun gereğince Yüksek Denetleme Kurulu'nun yapacağı denetleme, mahiyet ve hudutları yukarıda açıklandığı şe. kilde belirli ve sınırlı bir denetlemedir. Meselâ TRT Kurumunun vergi mïkellefi veya vergi sorumlusu sufatıyla kesmek veya ödemek niecburiyetinde olduğu vergilerin doğru hesaplamıp hesaplanmad1ginın tetkiki, yani vergi incelemesi yapılması ile yine kurumun riayetle mükellef olduğu masraf kanunlarmın doğru uygulanıp uygulanmadığını araştırılması Yüksek Denetleme Kurulu'nun yetki ve ihtisası dışında kalmaktadır. 33. maddedeki «bu kanundaki özel hü. kümler sakh kalmak» kaydi muvacehesinde «özerkliğì ihlâl edebiIecek bir denetim de olamaz. Esasen Hükûmet tasarısımın gerekçesinden de bu anlaşılmaktadır. Bahis konusu gerekçenin 7. fıkrasında aynen şu sözler yer almaktadır; "Yürütme organı ile Kurumun münasebeti düzenlenirken yürütme organma Kurum üzerindeki hiyerarşik bir merci yetkisi verilmemiş, Kurum Kanunda yazıl muayyen hallerde bir kamu tüzel kișisi olması ve hizmetinin bir âmme hizmeti bulunması gözönünde tutularak organların seçimi... yatırımları... hizmetin düzenlenmesi bakımından yürütme organı ile irtibat makamı olarak Basın Yayın ve Turizm Bakanlığına bağlanmıștır». İktidarın yetkilerini tahdit için Anayasa ile öngörülen özerkliğe sahip TRT üzerinde yürütme organına bir hiyerarşik yetki tanımak imkânı yoktur.

TRT nin Anayasal bünyesini ve kendisine tanınan ve tanınmas] gereken özerkliği çeșitli yönleri ile izah ettik. Kanaatımızca bu özerklik yalnız İdarî sahada değil, «malî sahada» da zarurîdir. Yukardan beri çeșitli konularla malî sahada özerkliğin bulunmamas: halinde doğan güçlükler gösterildi ve bu özerkliğin verilmemesi ha linde tam bir neticeye varılamıacağ ${ }_{1}$ da belirtildi. Anayasanın 121 nci maddesinin son fikrasına göre tarafsız hareket eden haber ajanslarına bile malî yardımın devam, edeceği prensibi konmuşken ve bư ladaki "malî yardımın" malî dèetim mânasına gelmediợi çok açıkken, tarafsız çalışacağı hususunda șüphe olmıyan TRT idaresinin ayni anlam içinde en azından aynı mahiyette bir "malî yardım» \$1nırları içinde kalması ve bumun devletçe denetlenememesi işin mahiyeti icabıdır. Anayasanın 121 inci maddesinin bütïn anlamı budur. 
Yukardan beri tetkik ettiklerimizle, tatbikatta TRT özerkliğinin var olduğunu söyliyemiyeceğiz. Tatbikatta özerklik daha gerçekleşmemiştir ve Anayasanın hükümleri tam uygulanmanaktadır. Anayasaya aykırı olan mevzuatın ve tutumun bir an evvel bertaraf edilmesi temenni edilir. 